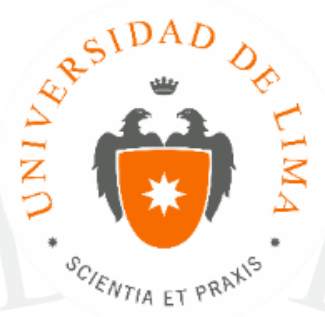

\title{
UN ESTUDIO COMPARATIVO SOBRE LA PROMOCIÓN DE DOS PELÍCULAS EXTRANJERAS EN EL MERCADO CINEMATOGRÁFICO PERUANO
}

Trabajo de investigación para optar a la Licenciatura en Comunicación

\section{Diana Carolina Concha Bravo \\ Código 20060277}

\author{
Asesora \\ Nathalia Hendrickx \\ Lima, Perú \\ Junio de 2018
}




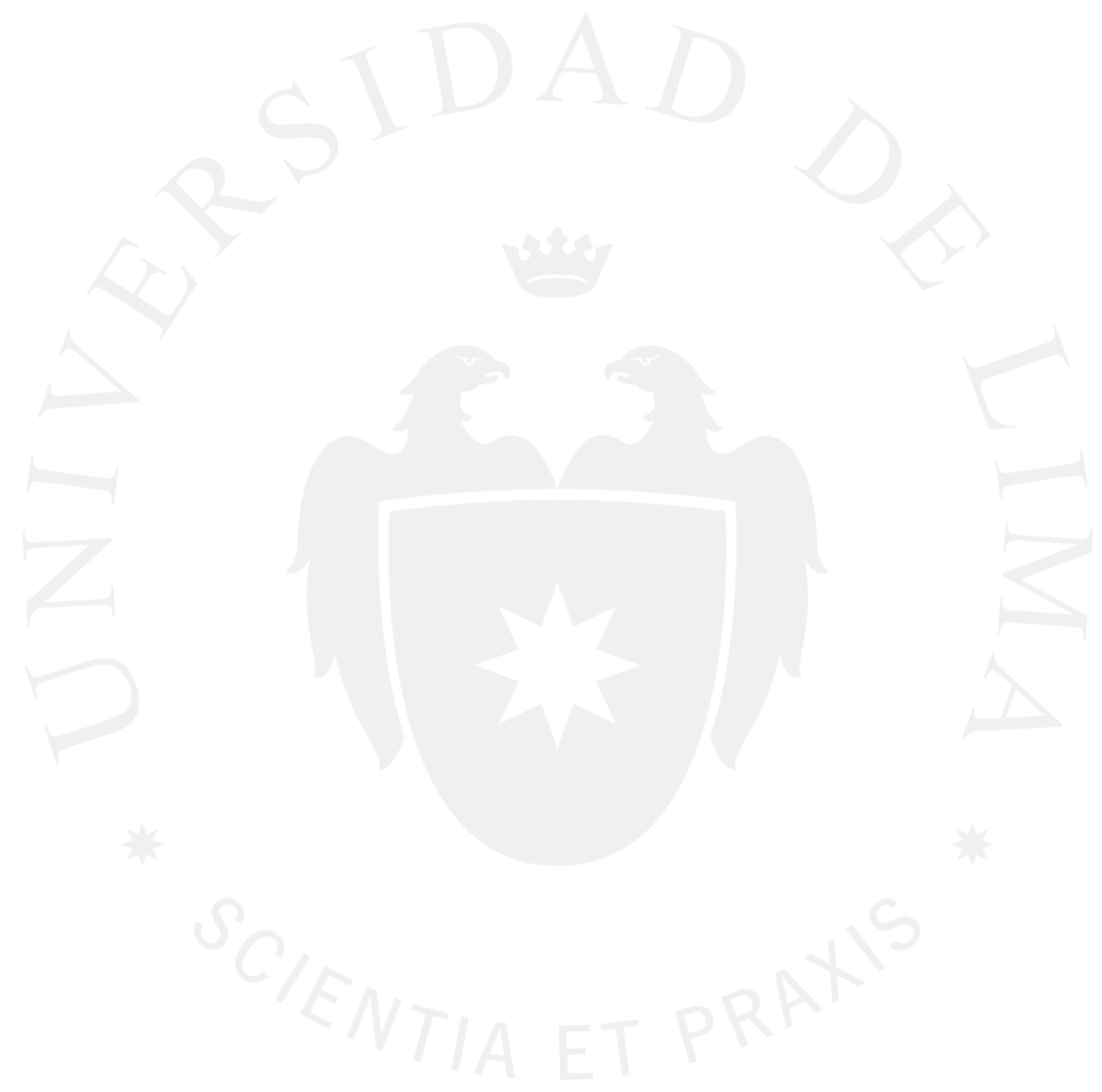


UN ESTUDIO COMPARATIVO SOBRE LA PROMOCIÓN DE DOS PELÍCULAS EXTRANJERAS EN EL MERCADO CINEMATOGRÁFICO PERUANO 


\section{RESUMEN}

Esta investigación identifica los elementos en las campañas promocionales de dos películas de acción estrenadas en salas peruanas en el 2016: Rescate suicida (The Crew) y Horizonte profundo: desastre en el Golfo (Deepwater Horizon). Según las decisiones tomadas por el distribuidor que llevó a cabo las campañas, se compararán las acciones realizadas para cada película, para definir cuáles son los aspectos más efectivos e importantes en la promoción de una película en el Perú y por qué los espectadores responden mejor a unos que a otros. Debido a que Rescate suicida llegó a su meta en espectadores, pero Horizonte profundo: desastre en el Golfo no lo logró, se analizará la importancia del marketing frente a otros factores inherentes a un estreno en cine.

PALABRAS CLAVE: Cine, películas, campañas de marketing, publicidad, distribución de cine

\section{ABSTRACT}

This research identifies the elements from the promotional campaigns of two action movies released in Peruvian theaters in 2016: The Crew and Deepwater Horizon. According to the decisions made by the distributor who led the campaigns, the actions made for each movie will be compared, to define which aspects are most effective and important in the promotion of a film in Peru and why the audience responses better to some than to others. Due to the fact that The Crew met its box-office goal, but Deepwater Horizon did not, the importance of marketing against other film release factors will be analyzed.

KEYWORDS: Cinema, motion pictures, marketing campaigns, advertising, film distribution 


\section{ÍNDICE}

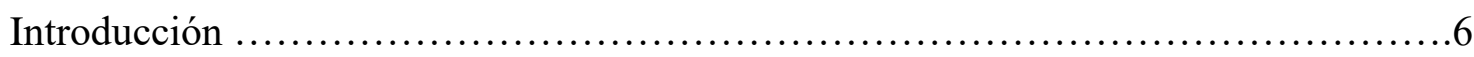

1. El mercado del cine en el Perú ..........................................6

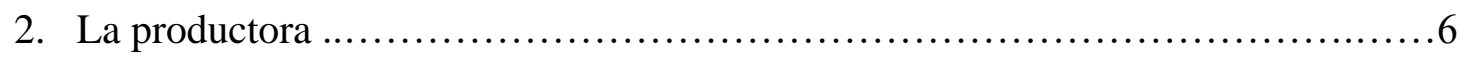

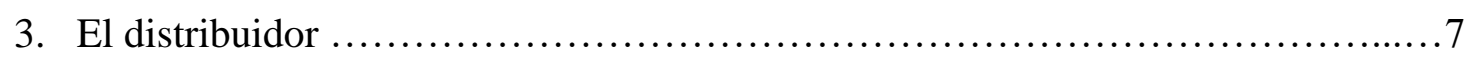

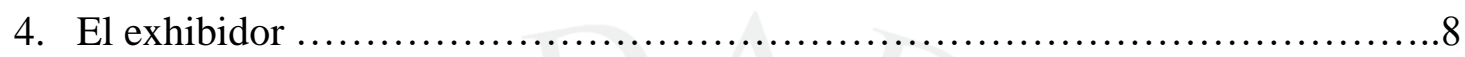

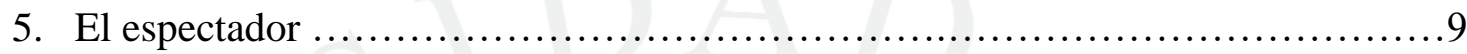

6. Campañas de promoción de películas de cine .................................11

Metodología .......................................................... 13

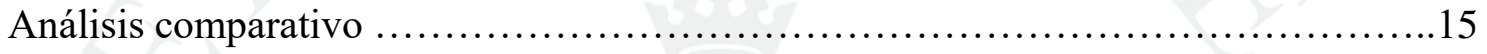

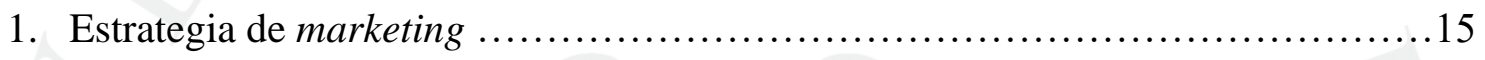

1.1. Factores generales ................................................... 15

1.2. Materiales creativos .................................................. 17

1.2.1. Pósteres de Horizonte profundo .....................................17

1.2.2. Material audiovisual de Horizonte profundo ...........................20

1.2.3. Pósteres de Rescate suicida .........................................21

1.2.4. Material audiovisual de Rescate suicida ............................23

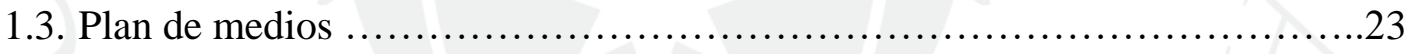

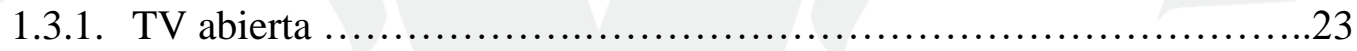

1.3.2. TV cable ................................................... 24

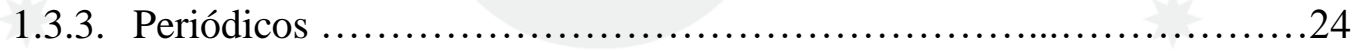

1.3.4. Radio ....................................................24

1.3.5. Vía pública ................................................25

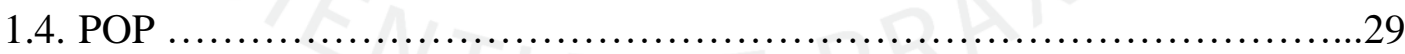

1.5. Promociones ........................................................... 37

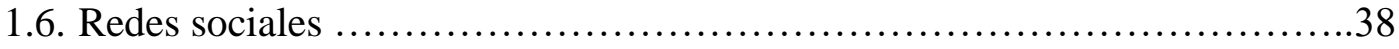

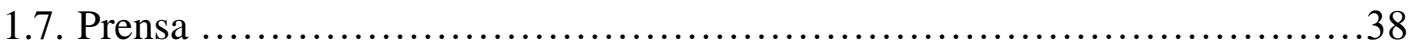

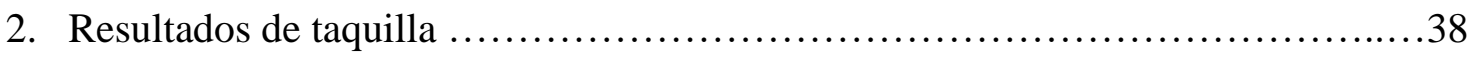

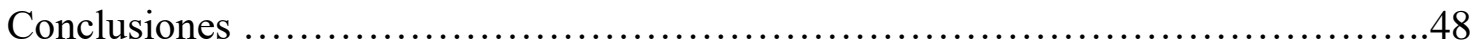

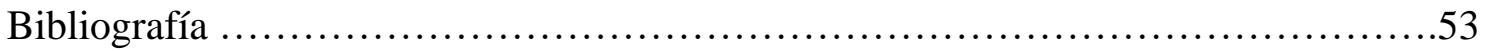

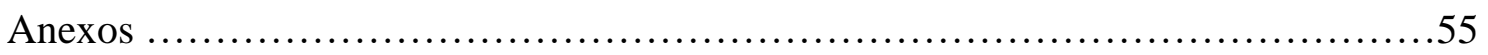




\section{INTRODUCCIÓN}

\section{El mercado del cine en el Perú}

En la actualidad, el estreno de películas de cine en el Perú tiene tres actores: la productora, el distribuidor y el exhibidor. Una serie de negociaciones entre ellos resulta en el estreno de películas en las salas de cine del país. Las actividades de las tres empresas son responsables del desarrollo de la industria del cine en el Perú.

\section{La productora}

La empresa productora realiza la película. Se encarga de todas las fases de producción de la película, desde el financiamiento hasta la toma de decisiones creativas sobre la misma. La productora tiene los derechos sobre la obra. Eventualmente, también decide cómo se distribuirá. Hay productoras que optan por encargarse de la distribución también, aunque en la mayoría de los casos eligen contratar o asociarse a una distribuidora.

Se considera que una película es de una nacionalidad específica según el país de origen de la productora. El modelo de trabajo de películas peruanas es distinto al de las películas extranjeras debido a que hay varias características que juegan a favor o en contra de la campaña. Una película peruana puede tener a favor estos puntos: temática local, idioma, actores y locaciones conocidas, posibles alianzas con marcas locales y la facilidad de tener y controlar una campaña de comunicación en el mismo país. Sin embargo, deben enfrentarse a las superproducciones de Hollywood, que tienen a su favor grandes presupuestos, mejoras tecnológicas, mayor experiencia y estrellas internacionales. Asimismo, hay películas de producción extranjera, no de Hollywood, que, de no volverse virales por algún motivo, tienen más desafíos: idioma, actores y locaciones desconocidas, culturas foráneas, etcétera. 
En el caso de cine extranjero, ya sea de Hollywood o de otra nacionalidad, el productor generalmente no puede establecer una estrategia de marketing idónea debido a que no conoce el mercado. Por este motivo, vende los derechos a un distribuidor, quien además de pactar su exhibición con las salas de cine u otros canales alternativos (televisión, VOD, festivales, etcétera), se encarga de planificar y ejecutar una campaña de marketing local (Miñarro, 2014). El beneficio es que una distribución conveniente para la película se logra negociando con los exhibidores. Los distribuidores ya tienen experiencia y buenas relaciones con ellos, por lo tanto, logran mejores condiciones de exhibición.

\section{El distribuidor}

Los distribuidores en el Perú se dividen en dos modelos: los de las majors y los independientes. Las majors son las empresas productoras consideradas como los grandes estudios de Hollywood: Disney, Fox, Warner, Universal, Sony, etcétera. Ellas tienen un trato exclusivo con un distribuidor en cada país, lo cual significa que solo distribuyen sus películas a través de dicho distribuidor. Por el tipo de producto, películas blockbuster con estrenos fijos a nivel mundial, las majors tienen el mayor porcentaje de participación en el mercado en el Perú.

Los distribuidores independientes ${ }^{1}$ consiguen películas de diversos productores sin exclusividad. Los derechos de una película que no pertenece a ninguna productora major pueden ser vendidos a la distribuidora que el productor elija. Según este modelo, a veces se venden paquetes de películas para negociar el costo de los derechos y los porcentajes de manera que tanto los productores y los distribuidores tengan el trato que más les convenga.

En el cuadro a continuación, están las empresas distribuidoras en el Perú, con el tipo de películas con las que han trabajado.

\begin{tabular}{|l|l|}
\hline DISTRIBUIDOR & PRODUCTORAS \\
\hline Cinecolor & Disney / Películas peruanas \\
\hline New Century Films & Fox / Warner / Películas peruanas \\
\hline UIP & Universal / Paramount \\
\hline Andes Films & Sony \\
\hline
\end{tabular}

\footnotetext{
1 Al mencionar distribuidores independientes, no se debe tomar en cuenta el concepto de "cine independiente", que se refiere a películas de un nivel de presupuesto y producción menor que las de Hollywood. No todas las películas con tratos de distribución independientes son de "cine independiente".
} 


\begin{tabular}{|l|l|}
\hline BF Distribution & Independientes / Películas peruanas \\
\hline Diamond Films & Independientes / Películas peruanas \\
\hline Delta Films & Independientes \\
\hline Tondero Distribución & Independientes / Películas peruanas \\
\hline Star Films & Independientes / Películas peruanas \\
\hline Mundo Films & Independientes \\
\hline
\end{tabular}

Fuente: Elaboración propia

Esta investigación toma el caso de dos películas de la distribuidora BF Distribution, cuya participación en el mercado es la mayor entre los distribuidores independientes (Rentrak, 2017). BF Distribution es una empresa de origen chileno que inició sus actividades en el Perú en el año 2011 con el estreno de la película El discurso del rey. Con trayectoria en el mercado chileno, incursionaron en el Perú con una sociedad con Cineplex Distribución, la rama de distribución de Cineplanet, que se mantiene hasta el presente. En el año 2013 la distribuidora incursionó en proyectos de cine peruano. Hoy en día BF Distribution tiene presencia en cuatro países de la región y distribuye prolíficamente películas de todo género.

La exhibición, específicamente en salas de cine, que se trata en este trabajo, comienza por una negociación en cuanto a qué complejos, cuántas salas, cuántas funciones y qué horarios tendrá la película. Asimismo, se define el porcentaje del ticket vendido que corresponde a cada parte y el pago de otros costos, como el VPF, un pago que se acordó por el cambio de la proyección en celuloide a la digital DCP (Digital Cinema Package).

\section{El exhibidor}

El exhibidor es la empresa que maneja las salas de cine. Ellos estrenan las películas en los cines tras una negociación con los distribuidores, quienes presentan su película como el título que resultará en las mejores ventas para el cine. Hoy en día, las salas de cine no se manejan de manera independiente. Son parte de una cadena que tiene un encargado de programación con quien se negocia para todos los cines de su marca (Akamine, 2017).

Hay seis empresas de multicines en el país, siendo Cineplanet, una empresa peruana, la más antigua e importante. Entró luego Cinemark, una cadena internacional. UVK Multicines, Cinerama y Top Rank (que manejan Cinestar y Movie Time), 
empresas peruanas, fueron apareciendo y finalmente llegó la cadena mexicana Cinépolis. Estas empresas se reparten el mercado de la siguiente manera:

\section{EXHIBIDORES}

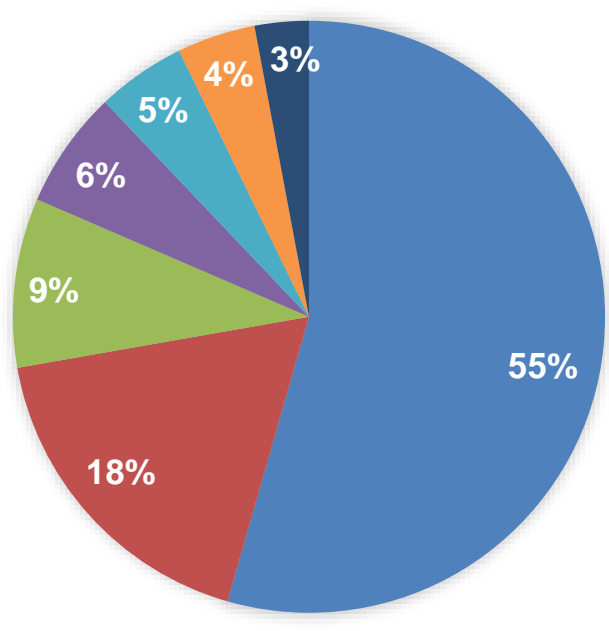

- Cineplanet

- Cinemark

- CineStar

- Cinépolis

- UVK

- Cinerama

- Movie Time

Fuente: Rentrak, 2017

El mercado ha venido creciendo constantemente cada año, tanto la demanda como la oferta; hoy hay 600 pantallas en casi 100 cines en el Perú, lo cual permite el estreno de mayor cantidad y variedad de películas.

\section{El espectador}

El público de cine en el país tiene un perfil predominante que se toma en cuenta al elegir una película para estrenar localmente. Esto no significa que una película cuyo público objetivo no es representado por el espectador de cine promedio no vaya a funcionar, pero ayuda al distribuidor a trazar una meta realista al realizar su estrategia de marketing. Este perfil es el siguiente: hombres y mujeres de 18 a 35 años, de nivel socioeconómico C y con al menos secundaria completa (High End Cine, 2015).

Los géneros también son un factor importante. Las preferencias en el mercado local son acción, comedia, terror y animación. 


\section{GÉNEROS}

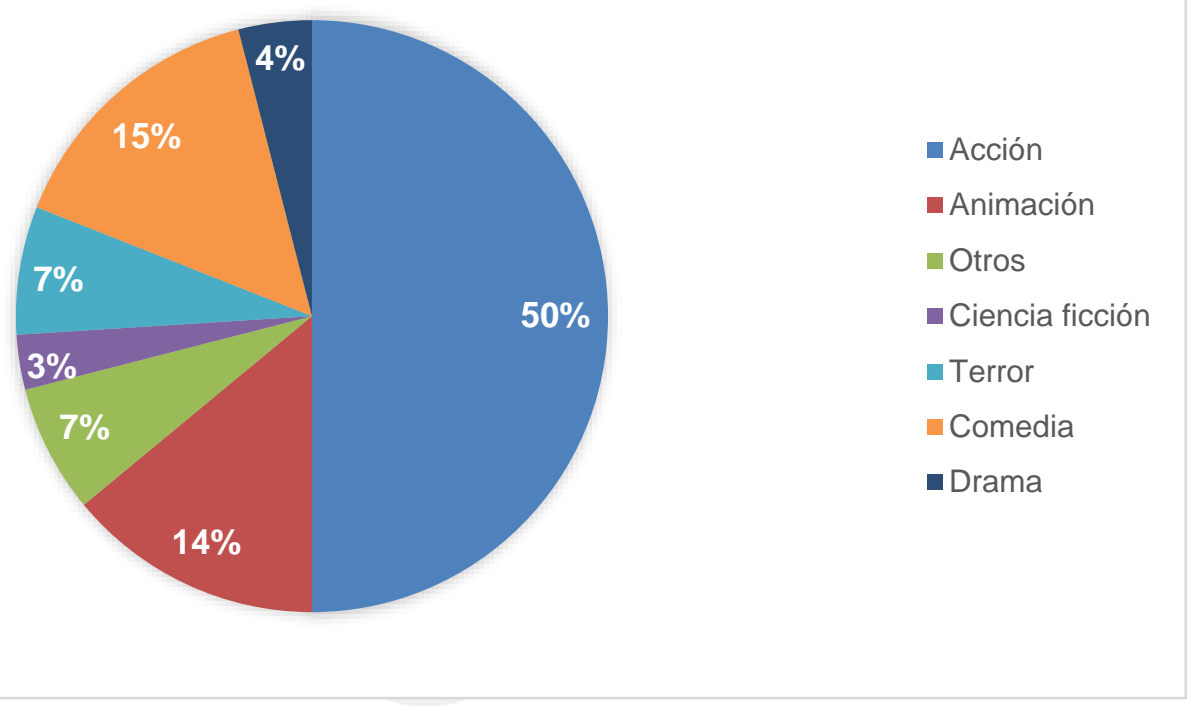

Fuente: Rentrak, 2017

Las películas seleccionadas para esta investigación son del género de acción, como prioritario, que es el género preferido en el mercado peruano, y drama como género secundario. Ambos filmes se refieren a desastres, lo que se considera un tema que vende fácilmente en el Perú, así como el terror. En el año 2016 se estrenaron 30 películas de acción y 6 películas que tuvieron el concepto de desastre en sus campañas.

\begin{tabular}{|l|l|l|l|l|}
\hline Título & Sinopsis Nacionalidad & $\begin{array}{l}\text { Fecha de } \\
\text { estreno }\end{array}$ & Asistentes \\
\hline La quinta ola & $\begin{array}{l}\text { Tras una planificada invasión } \\
\text { extraterrestre de la Tierra en cuatro } \\
\text { oleadas que ha acabado casi con toda } \\
\text { la humanidad, la joven Cassie } \\
\text { Sullivan intenta encontrar a su } \\
\text { hermano pequeño mientras trata de } \\
\text { sobrevivir junto a otros. }\end{array}$ & $21 / 01 / 2016$ & 928.078 \\
\hline $\begin{array}{l}\text { Horas } \\
\text { contadas }\end{array}$ & $\begin{array}{l}\text { La Guardia Costera realiza un } \\
\text { valiente esfuerzo de rescate en la } \\
\text { bahía del Cabo Cod, luego de que un } \\
\text { par de embarcaciones petroleras son } \\
\text { destruidas durante una tormenta de } \\
\text { nieve en 1952. }\end{array}$ & & & \\
\hline La ola & $\begin{array}{l}\text { El experimentado geólogo Kristian } \\
\text { Eikfjord y sus colegas miden } \\
\text { pequeños cambios geológicos bajo } \\
\text { tierra. Kristian se preocupa y su peor } \\
\text { pesadilla está a punto de volverse } \\
\text { realidad, cuando la alarma se } \\
\text { enciende y el desastre se vuelve } \\
\text { inevitable. Con menos de diez } \\
\text { minutos para reaccionar, se vuelve }\end{array}$ & & & \\
\end{tabular}




\begin{tabular}{|c|c|c|c|c|}
\hline & $\begin{array}{l}\text { una carrera contra el tiempo para } \\
\text { salvar a cuantos se pueda, incluyendo } \\
\text { su propia familia. }\end{array}$ & & & \\
\hline $\begin{array}{l}\text { Día de la } \\
\text { independencia: } \\
\text { contraataque }\end{array}$ & $\begin{array}{l}\text { Utilizando tecnología obtenida de los } \\
\text { extraterrestres } 20 \text { años atrás, las } \\
\text { naciones de la Tierra han colaborado } \\
\text { durante este tiempo en la elaboración } \\
\text { de un gigantesco programa de } \\
\text { defensa global para proteger el } \\
\text { planeta. Pero no es seguro que el } \\
\text { programa pueda prepararlos para } \\
\text { hacer frente a la avanzada e inaudita } \\
\text { fuerza de los atacantes. Quizá solo la } \\
\text { inventiva de unos pocos valientes } \\
\text { hombres y mujeres pueda evitar la } \\
\text { nueva amenaza y la destrucción del } \\
\text { mundo, de nuevo al borde de la } \\
\text { extinción. }\end{array}$ & $\begin{array}{l}\text { Estados } \\
\text { Unidos }\end{array}$ & $23 / 06 / 2016$ & 818.115 \\
\hline $\begin{array}{l}\text { Horizonte } \\
\text { profundo: } \\
\text { desastre en el } \\
\text { Golfo }\end{array}$ & $\begin{array}{l}\text { Filme basado en los eventos } \\
\text { sucedidos en el Golfo de México en } \\
\text { el 2010, cuando una explosión } \\
\text { accidental en la plataforma petrolífera } \\
\text { Deepwater Horizon le causó daños } \\
\text { irreparables que acabaron liberando } \\
\text { miles de galones de petróleo en el } \\
\text { golfo de México en los Estados } \\
\text { Unidos, el peor derrame de petróleo } \\
\text { nunca antes visto. }\end{array}$ & $\begin{array}{l}\text { Estados } \\
\text { Unidos }\end{array}$ & $06 / 10 / 2016$ & 98.493 \\
\hline $\begin{array}{l}\text { Rescate } \\
\text { suicida }\end{array}$ & $\begin{array}{l}\text { Un joven piloto es despedido de la } \\
\text { fuerza aérea militar después de } \\
\text { desobedecer una orden absurda, y } \\
\text { consigue un trabajo como copiloto en } \\
\text { una aerolínea civil. Durante un vuelo } \\
\text { a Asia, su tripulación recibe un } \\
\text { mensaje de socorro de una isla } \\
\text { volcánica, y toma la decisión de } \\
\text { intentar una misión de rescate. }\end{array}$ & Rusia & $03 / 11 / 2016$ & 118.532 \\
\hline
\end{tabular}

Fuente: Elaboración propia

Las películas elegidas para la comparación de campañas en este trabajo fueron las últimas dos, Horizonte profundo y Rescate suicida, debido a que no tenían el respaldo de una productora grande, fueron trabajadas por el mismo distribuidor local independiente y no fueron blockbusters internacionales, como fue el caso de Día de la independencia y La quinta ola.

\section{Campañas de promoción de películas de cine}

La estrategia de marketing de cine nace con la producción de la película. Desde la noción del concepto, la elección del elenco hasta la misma película como producto finalizado, las concepciones ideadas para la realización de la película son inherentes a la misma. En el caso de la distribución de películas internacionales en el Perú, toda esta 
primera etapa escapa de las manos del distribuidor. Por lo tanto, las actividades de marketing de cine se reparten entre lo que el productor ofrece al distribuidor y lo que el mismo distribuidor produce.

\section{Lista de actividades de marketing de cine (adaptado de Blume, 2006)}

Creación de materiales publicitarios (pósteres, avances, televisión, radio, redes sociales).

Planeamiento de actividades de prensa (entrevistas con periódicos, revistas, televisión, radio, internet).

Planeamiento de publicidad y prensa que coincidan con el estreno.

Organización del junket de prensa.

Negociación de programación con exhibidores.

Función de prueba para determinar potencial e influenciar materiales de marketing y posicionamiento.

Envío de copias a cines.

Monitoreo del rendimiento de la película en cada pantalla y negociaciones sobre la extensión del tiempo de exhibición.

Extensión o reducción de publicidad y actividades promocionales según el rendimiento de la película.

Negociación y coordinación de tratos comerciales con marcas locales para proveer promociones cruzadas por sus productos y la película.

Fuente: Kerrigan, 2010.

La división del trabajo del productor y del distribuidor depende de la negociación, pero generalmente el productor provee estos puntos:

- Póster: El productor suele tener un diseño, pero el distribuidor decide al final lo que conviene para el territorio.

- Avance: Por la disponibilidad limitada de material de video, el avance por lo general es directamente provisto por el productor.

- Organización de junket de prensa: Por su cercanía con el elenco y equipo de producción, el productor organiza el junket y pide al distribuidor los datos de los periodistas invitados por territorio.

- El resto de elementos descritos en la lista es supervisado por el distribuidor según la estrategia para sus territorios.

En esta investigación, se van a tomar en cuenta las acciones de promoción de la película al público, el trabajo del distribuidor. No se indagará en la toma de decisiones del productor, pero sí en cómo el distribuidor usa los recursos provistos por la casa productora. 


\section{METODOLOGÍA}

Los objetivos del trabajo consisten en descubrir qué acciones en la promoción de una película extranjera estrenada en el Perú logran que esta tenga un rendimiento positivo en taquilla. Para definirlo se analiza el escenario desde tres perspectivas: las campañas de marketing, el público peruano y las características propias de las películas.

Para analizar las campañas de marketing se hizo una comparación de datos y campañas de dos películas de características similares: Horizonte profundo: desastre en el Golfo (Deepwater Horizon) y Rescate suicida (The Crew). Ambas películas extranjeras, del género de acción con temática de desastre, fueron estrenadas el mismo año por BF Distribution y con presupuestos de campaña muy similares. Rescate suicida tuvo mejores resultados que Horizonte profundo. Con esta comparación se espera descubrir qué acciones o características pudieron haber marcado la diferencia.

Se requiere profundizar en las motivaciones del espectador para ir a ver una película específica. Para esto, los datos conseguidos en la comparación de campañas se contrastaron con la información de estudios del mercado peruano para descubrir por qué el espectador elige ver una película ante todas las opciones que se le presentan. Asimismo, se entrevistó a la gerente de marketing y comercial de Cinemark, Diana López, buscando insights sobre el consumidor desde el punto de vista del exhibidor.

Finalmente, también se entrevistó a la gerente de marketing de la distribuidora, Gabriela Absi, para descubrir los motivos que llevaron a la empresa a tomar las decisiones sobre las campañas. Se toma en cuenta tanto el punto de vista del distribuidor como la opinión y experiencia del exhibidor en cuanto al alcance de películas con las características que tienen las estudiadas en este trabajo. El objetivo es 
averiguar qué se debe explotar de una película extranjera como producto en el mercado peruano, para descubrir cuáles son los beneficios y riesgos de estrenar este tipo de películas en el país. 


\section{ANÁLISIS COMPARATIVO}

Según la comparación de las campañas de marketing y de los resultados de ambas películas, se pueden encontrar algunas diferencias que explican la variación en los resultados.

\section{Estrategia de marketing}

\subsection{Factores generales}

\begin{tabular}{|c|c|c|}
\hline Título & $\begin{array}{l}\begin{array}{l}\text { Rescate suicida (The Crew / } \\
\text { Ekipazh) }\end{array}\end{array}$ & $\begin{array}{l}\text { Horizonte profundo: desastre en el } \\
\text { Golfo (Deepwater Horizon) }\end{array}$ \\
\hline Nacionalidad & Rusa & Estadounidense \\
\hline Fecha de estreno & 6 de octubre del 2016 & 3 de noviembre del 2016 \\
\hline Sinopsis & $\begin{array}{l}\text { Una historia sobre la valentía, el } \\
\text { sacrificio y la dignidad humana } \\
\text { puestos a prueba por el poder } \\
\text { implacable de la naturaleza. Un } \\
\text { joven piloto es despedido de la } \\
\text { fuerza aérea militar después de } \\
\text { desobedecer una orden absurda. } \\
\text { Consigue un trabajo como copiloto } \\
\text { en una aerolínea civil. Al ser } \\
\text { brutalmente honesto y directo, no } \\
\text { está en las mejores condiciones con } \\
\text { sus nuevos compañeros. Durante un } \\
\text { vuelo a Asia, su tripulación recibe } \\
\text { un mensaje de socorro de una isla } \\
\text { volcánica y toma una decisión para } \\
\text { intentar una misión de rescate. ¿Va } \\
\text { a tener éxito? ¿Podrán sobrevivir al } \\
\text { desastre? Tienen una sola } \\
\text { oportunidad de descubrir que son } \\
\text { un equipo. }\end{array}$ & $\begin{array}{l}\text { La película se basa en los eventos } \\
\text { sucedidos en el Golfo de México el } \\
20 \text { de abril del } 2010 \text {, cuando un } \\
\text { accidente causó una explosión en la } \\
\text { plataforma petrolífera Deepwater } \\
\text { Horizon, que le causó daños } \\
\text { irreparables y la hundió, lo cual } \\
\text { liberó miles de galones de petróleo } \\
\text { en el Golfo de México en los } \\
\text { Estados Unidos, el peor derrame de } \\
\text { petróleo nunca antes visto, donde } \\
\text { fallecieron } 11 \text { personas y salieron } \\
\text { heridas otras } 16 \text {. }\end{array}$ \\
\hline Formatos & 2D Doblado & 2D Subtitulado y Doblado \\
\hline Género & $\begin{array}{l}\text { Principal: Acción } \\
\text { Secundario: Drama / Desastre }\end{array}$ & $\begin{array}{l}\text { Principal: Acción } \\
\text { Secundario: Drama / Desastre }\end{array}$ \\
\hline Elenco & $\begin{array}{l}\text { Danila Kozlovsky, Vladimir } \\
\text { Mashkov, Agne Grudyte }\end{array}$ & $\begin{array}{l}\text { Mark Wahlberg, Kate Hudson, John } \\
\text { Malkovich, Kurt Russell y Dylan } \\
\text { O’Brien. }\end{array}$ \\
\hline
\end{tabular}




\begin{tabular}{|l|l|l|}
\hline Público objetivo & $\begin{array}{l}\text { Hombres y mujeres mayores de 25 } \\
\text { años. } \\
\text { NSE B, C y D }\end{array}$ & $\begin{array}{l}\text { Hombres y mujeres mayores de 25 } \\
\text { años. } \\
\text { NSE A, B y C }\end{array}$ \\
\hline $\begin{array}{l}\text { Proyección de } \\
\text { admisiones }\end{array}$ & 100.000 espectadores & 120.000 espectadores \\
\hline $\begin{array}{l}\text { Presupuesto de } \\
\text { campaña }\end{array}$ & S/ 123.860 & S/ 117.270 \\
\hline $\begin{array}{l}\text { Propuesta } \\
\text { copiado }\end{array}$ & $\begin{array}{l}\text { Cinemark: 11/12 salas } \\
\text { Cineplanet: } 27 / 32 \text { salas } \\
\text { dinerama: 7/9 salas } \\
\text { Plaza Jesús María: } 1 / 1 \text { salas } \\
\text { Cinépolis: 4/4 salas } \\
\text { Cine Star: } 14 / 18 \text { salas } \\
\text { Movietime: } 4 / 6 \text { salas } \\
\text { UVK: } 8 / 9 \text { salas } \\
\text { Total: 76/91 salas }\end{array}$ & $\begin{array}{l}\text { Cinemark: } 10 / 12 \text { salas } \\
\text { Cineplanet: } 27 / 32 \text { salas } \\
\text { Cinerama: 4/9 salas } \\
\text { Plaza Jesús María: } 1 / 1 \text { salas } \\
\text { Cinépolis: 4/4 salas } \\
\text { Cine Star: } 12 / 18 \text { salas } \\
\text { Movietime: } 1 / 6 \text { salas } \\
\text { UVK: } 8 / 9 \text { salas } \\
\text { Total: } 67 / 91 \text { salas }\end{array}$ \\
\hline
\end{tabular}

Las características argumentales de ambas películas son muy similares. Ambas tratan de historias de desastre en las que un personaje insólito encuentra valor y comienza a realizar actos heroicos para salvar a todos. La diferencia está en que Horizonte profundo se basa en hechos reales, lo cual le da mayor potencial de material a promocionar y, por ende, interés del público.

Sin embargo, la diferencia más importante para la campaña de marketing en este caso es la nacionalidad de la producción. Rescate suicida es una película de Rusia, en idioma y con actores rusos que no son conocidos en el Perú. A partir del desafío de estrenar una película así, se comienzan a tomar decisiones diferentes.

La proyección de admisiones de Rescate suicida fue un poco menor a la de Horizonte profundo, aunque su público objetivo estaba conformado por un sector mucho más amplio. El nivel socioeconómico B, C y D es el público popular y el que predomina en el mercado de cine. El copiado propuesto para la película rusa es mayor, ya que incluye más salas del sector popular, cines en provincias de las cadenas Cinerama, Cine Star y Movietime, que fueron omitidas para Horizonte profundo. La razón de esta desproporción es que las salas omitidas para Horizonte profundo son pequeñas y llevan poco público. Hay más cantidad de plazas para Rescate suicida, apuntando a alcanzar una mayor amplitud, mientras que Horizonte profundo buscaba llegar de manera más cerrada al público A, B y C.

También se optó por ofrecer la película rusa solo en formato doblado, porque el público objetivo la preferiría completamente en español a oírla en ruso y tener que 
seguir subtítulos. Además, los mismos exhibidores prefieren exhibir películas de idioma extranjero solo en formato doblado.

Finalmente, el presupuesto de Rescate suicida fue mayor al de Horizonte profundo debido a que el público popular es mucho más amplio, y que la película rusa no tenía elementos propios (actores, temas populares, prensa internacional) que la promocionaran; entonces toda la comunicación saldría de la campaña de marketing de la distribuidora.

Cabe mencionar que la productora de Horizonte profundo era más cerrada que la de Rescate suicida. La elección del nombre localizado, en el caso de Horizonte profundo, fue una decisión regional irrefutable. El nombre es la traducción literal del título en inglés Deepwater Horizon, que era el nombre del navío que tuvo el accidente. El problema es que, al traducirlo, pierde el significado y representa más drama que acción. Sin embargo, Rescate suicida fue un nombre elegido por BF Distribution, en lugar de traducir el título original Ekipazh o The Crew en inglés, que significa 'la tripulación'. El título Rescate suicida expresa intensidad y acción, y queda muy bien con la estrategia de comunicación.

\subsection{Materiales creativos}

Habiéndose definido un público y una meta, toca definir cómo se comunicaría la película. Al ser ambas películas extranjeras, las productoras tenían ya estrategias definidas para sus territorios y materiales creativos aprobados por la producción y el elenco. Es trabajo del distribuidor ver si esos materiales funcionan para la campaña

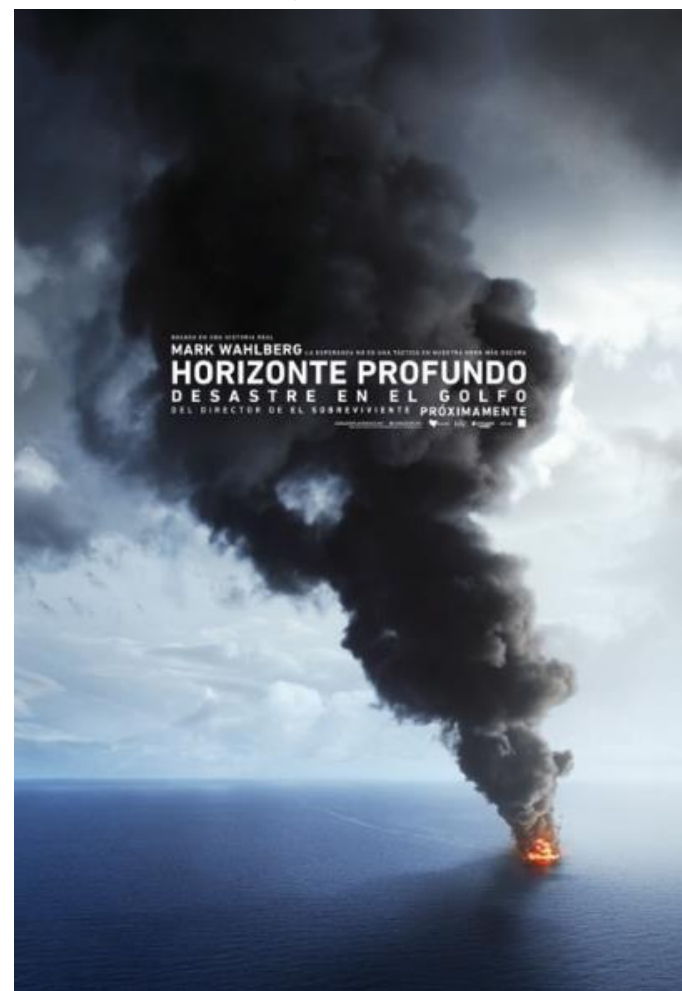
local, o proponer otras opciones.

\subsubsection{Pósteres de}

\section{Horizonte profundo}

\section{Arte Teaser}

Este arte se usó para promocionar la película por redes sociales y en algunos artes de socios promocionales, debido a que, por contrato, la 
imagen de los actores no podía salir con marcas ajenas a la película.

No se consideró para el resto de la campaña porque no expresaba urgencia ni acción. Además, no tiene la imagen de los actores, que es uno de los puntos más fuertes de esta película.

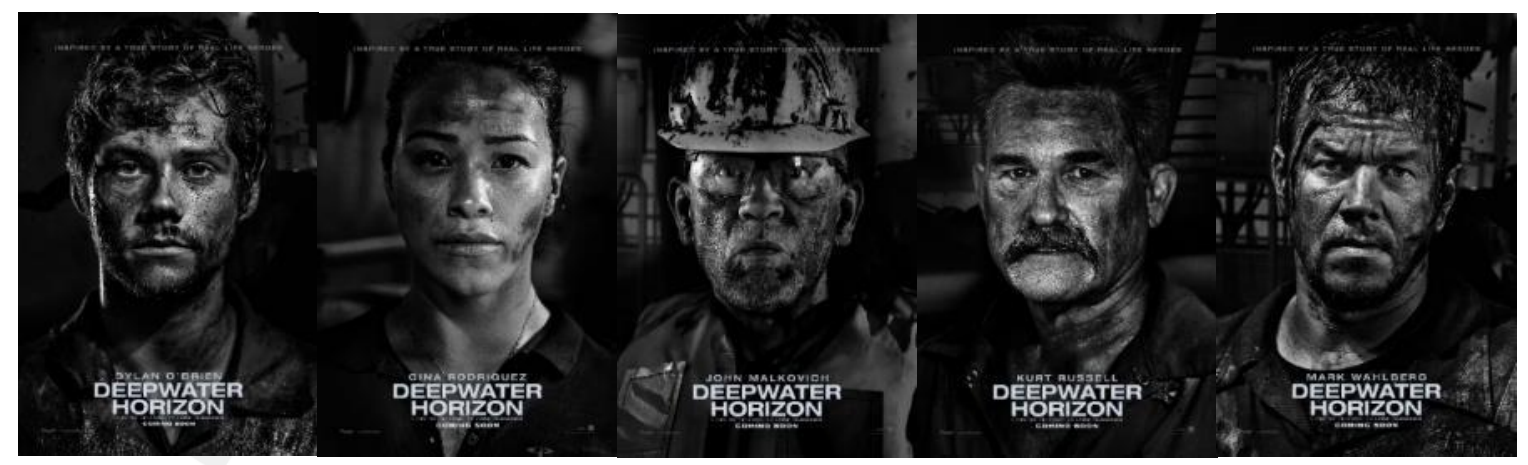

Pósteres de personajes

En esta propuesta, se lanzaron cinco afiches de los actores principales de la película, reforzando el concepto de heroísmo y aprovechando la fama de los artistas. Para el Perú, se optó por usarlo solo en redes sociales porque expresaba solo drama, debido a que las imágenes están en blanco y negro y los semblantes de los actores son serios.

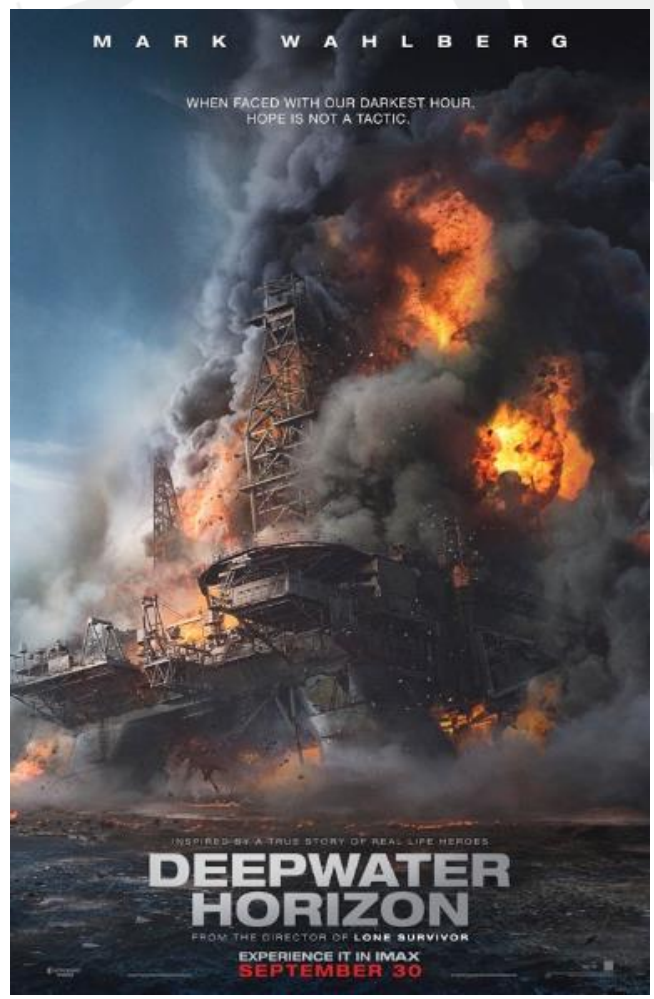

Póster Rig Explosion

Este iba a ser considerado el arte final; sin embargo, aunque demostraba más acción que drama, aún faltaba la imagen de los actores. Por lo menos, se buscaba que saliera Mark Wahlberg.

Se usó en redes sociales, y al igual que el teaser, para artes con socios promocionales donde no se podía mostrar la imagen de los actores. 


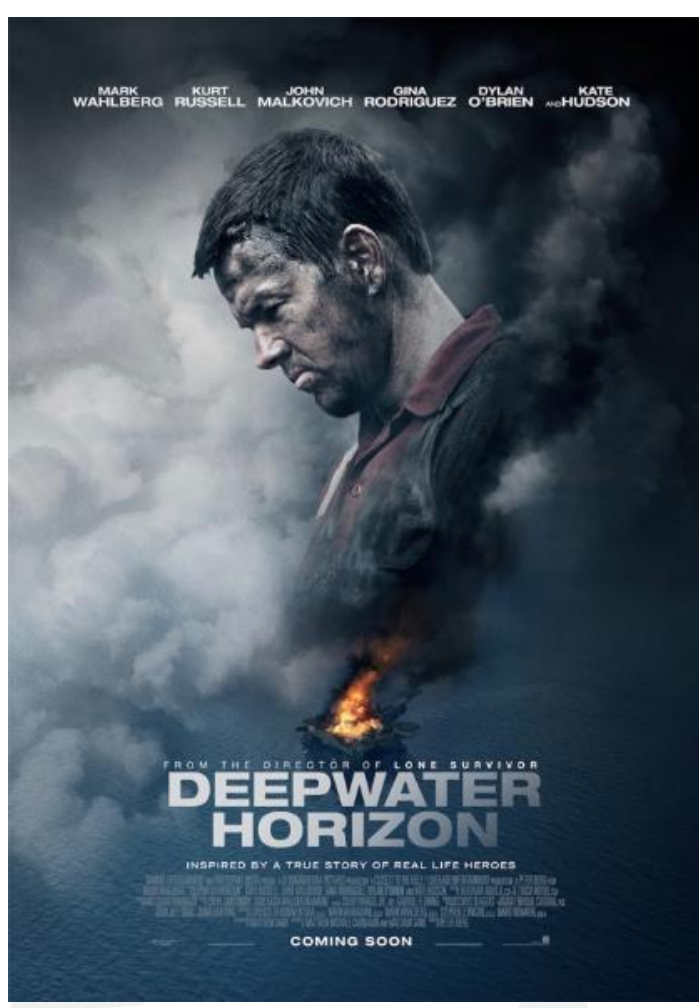

\section{Póster final de Estados Unidos}

La productora lanzó su arte final para la campaña en Estados Unidos, donde se ve la imagen de Mark Wahlberg, los nombres del elenco estelar en la parte superior y el bloque de créditos en la parte inferior.

Para el Perú, el afiche no cumplía. Aunque sale el rostro de Mark Wahlberg, ni su expresión ni la imagen del desastre expresan acción, urgencia o intensidad. De hecho, se ve como un drama que es el concepto que se trataba de evitar en el país.

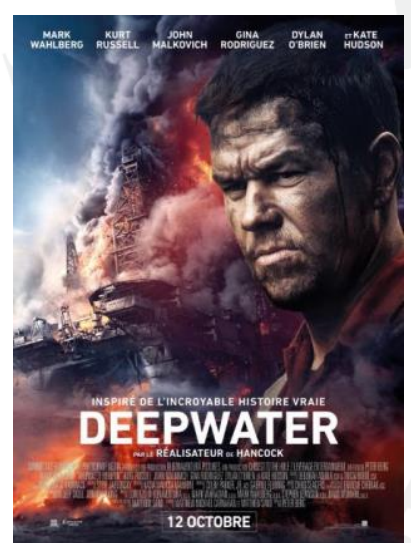

El distribuidor francés logró que se le aprobase una propuesta donde se incluía la acción del póster rig explosion con el rostro de Mark Wahlberg.

Este afiche cubría los requerimientos estratégicos para la campaña en el Perú y fue adaptado para ser el arte final.

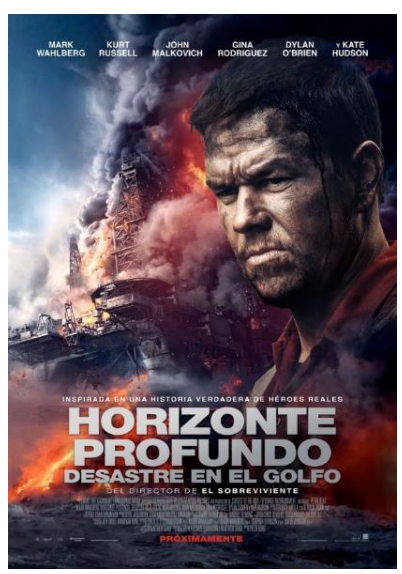

\section{Póster final del Perú}

En la localización del póster francés, cabe mencionar que se priorizó la primera parte del título: "Horizonte profundo", a la segunda parte "Desastre en el golfo", ya que el título completo era demasiado largo. Se cambió el llamado antes del título al 
mismo usado en Estados Unidos y, en lugar de mencionar que el director era el mismo de Hancock, se usó "El sobreviviente".

Este afiche se imprimió para su uso en cines y se utilizó como arte principal para toda la campaña.

1.2.2. Material audiovisual de Horizonte profundo

\begin{tabular}{|l|l|}
\hline \multirow{4}{*}{ Avances } & Avance 1, teaser \\
\cline { 2 - 2 } & Avance 2, principal \\
\cline { 2 - 2 } & Avance 3, principal acortado \\
\hline \multirow{2}{*}{ Spots } & 18 spots de 30 segundos \\
\cline { 2 - 2 } & 9 spots de 15 segundos \\
\hline Clips & 6 Clips \\
\hline Featurettes & 4 Featurettes \\
\hline
\end{tabular}

Igual que con los artes, el productor preparó materiales audiovisuales comenzando por varias versiones de avances, que felizmente sí expresaban los conceptos de género y temática de la estrategia local. El teaser se usó en cines y redes sociales, solo en formato subtitulado. No se invirtió en su doblaje ya que era un elemento muy prematuro. El avance principal sí se dobló al español y se usó también subtitulado en cines y redes sociales. Finalmente, enviaron un avance acortado que no fue usado. Se le dio prioridad al avance principal.

Luego se enviaron varios spots promocionales de 15 y 30 segundos. Por su duración, estos expresaban un solo concepto por modelo. Además, dentro de los requerimientos de la campaña, no se necesitó usar todo el material enviado. Solo se tomó el spot de 15 más relevante para la campaña y se le agregó locución en español para la campaña en televisión. Este mismo spot se acortó a 10 segundos y se adaptó a formato vertical para la campaña en las pantallas de iWalls ${ }^{2}$ en centros comerciales.

Se seleccionaron escenas de la película para ser publicadas como clips. Dos de estos se subtitularon y fueron usados para la campaña en redes sociales.

Finalmente, aprovechando que la película estuvo basada en hechos reales, se hicieron featurettes, que son videos de tipo reportaje donde se muestran tomas detrás de

${ }^{2}$ Soporte de publicidad en pantallas ubicadas en centros comerciales. 
cámara con entrevistas y cuyo objetivo es profundizar en los temas resaltantes de la producción de la película. Dos featurettes fueron subtitulados y compartidos en redes sociales y con la prensa local.

\subsubsection{Pósteres de Rescate suicida}

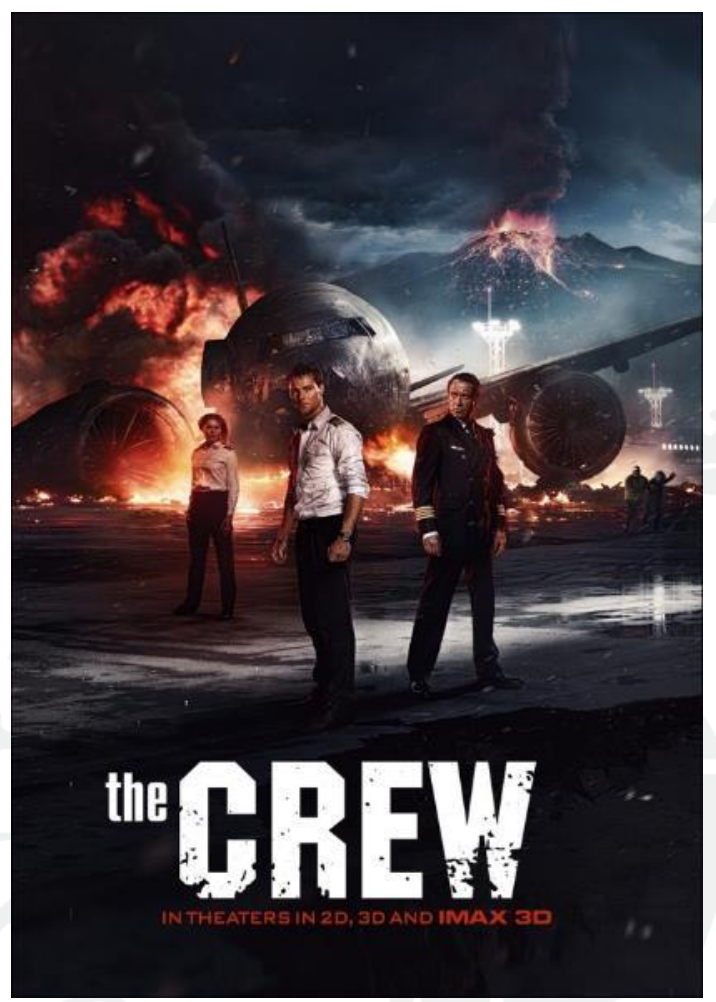

Póster 'teaser'

El arte presenta desastre y acción en un primer plano. La estrategia extranjera pareció ser muy similar a la local.

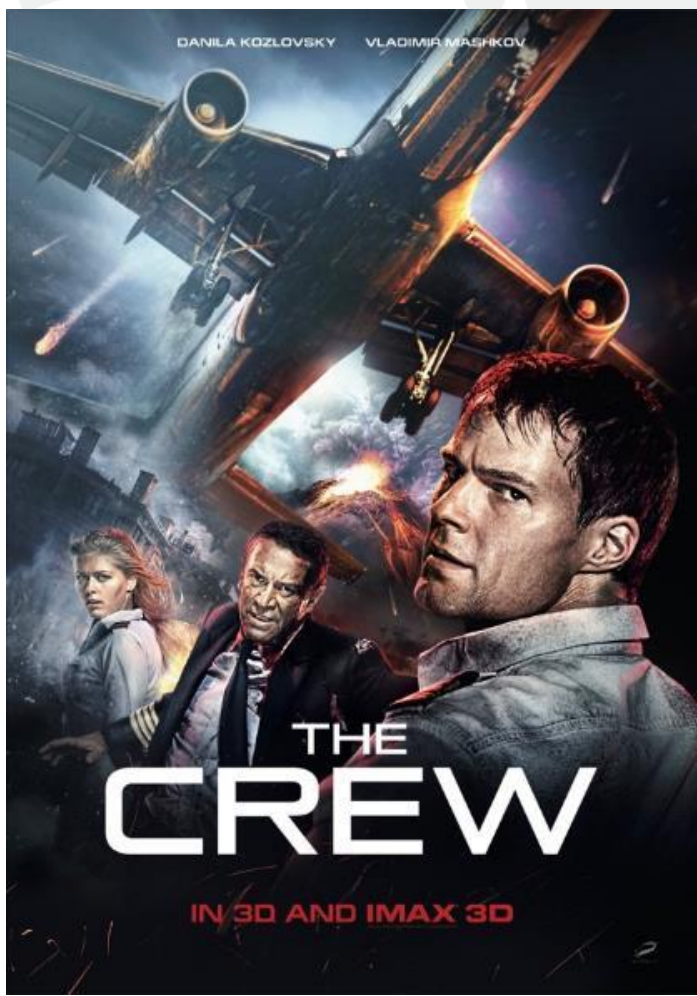

Póster final

En este afiche las expresiones de los actores son mejores. Sin embargo, no muestra el desastre en primer plano, y localmente los actores no son conocidos, así que no sirve tenerlos adelante. 


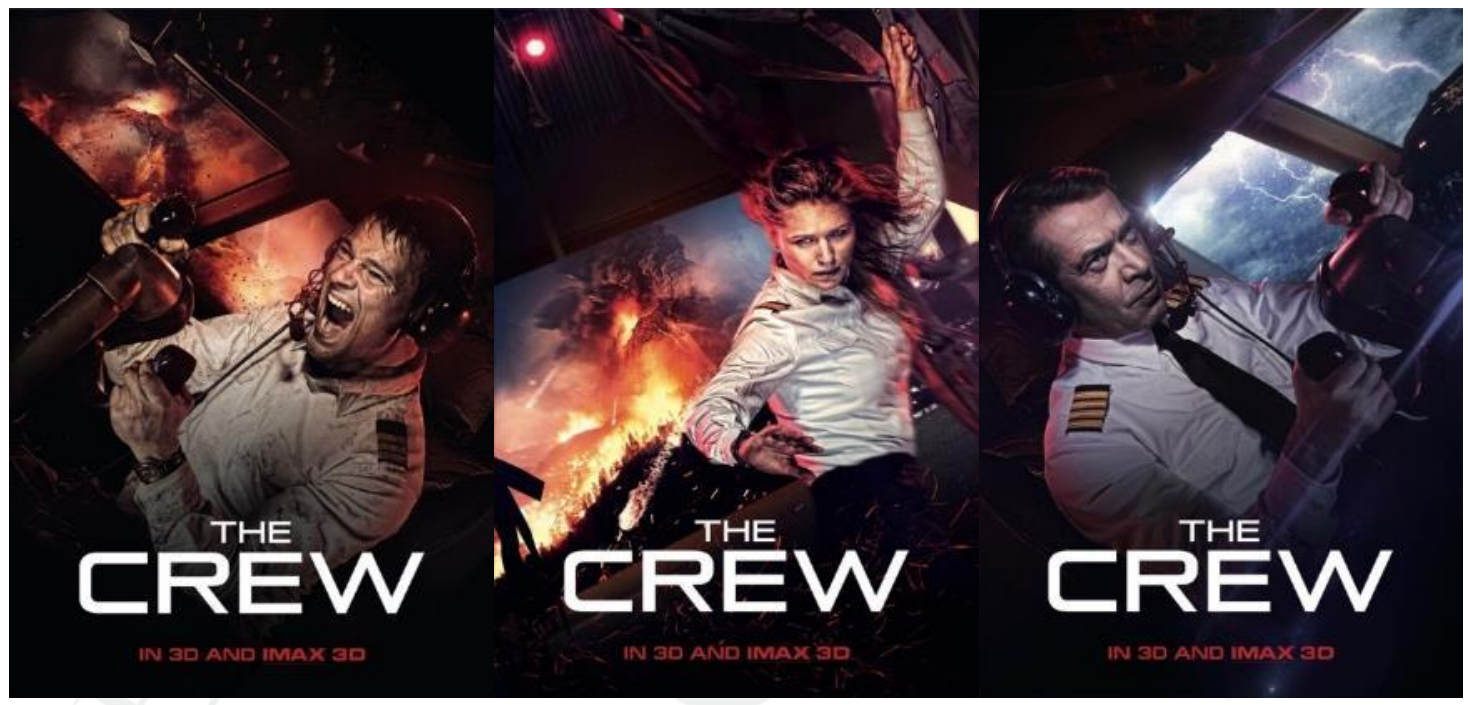

Pósteres de personajes

Los pósteres son muy buenos en cuanto a conceptos. Los actores expresan mucha intensidad, se ve acción y desastre. Sin embargo, debido a que los actores no son conocidos, no se usaron los afiches en las partes masivas de la campaña (medios, promociones con socios, prensa), solo en algunos elementos POP. ${ }^{3}$

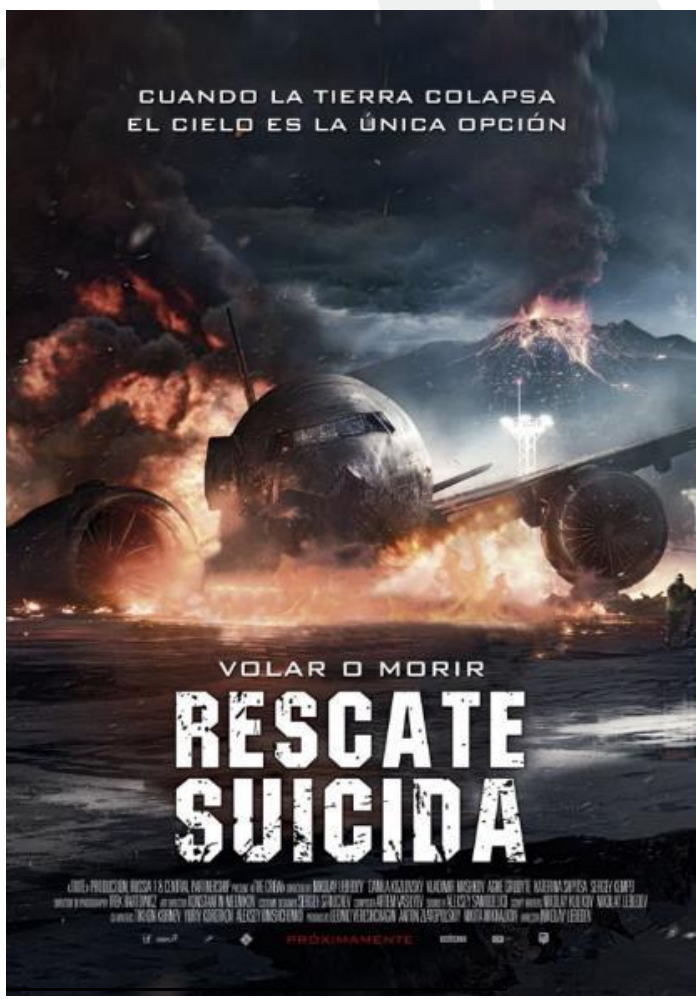

\section{Póster final del Perú}

BF Distribution logró que se aprobara una propuesta de afiche basada en el arte teaser, donde se ve en primer plano el desastre, retirando a los actores. Se agregó el tagline "Cuando la tierra colapsa el cielo es la única opción" y "Volar o morir". Asimismo, el título presenta una fuente corroída, pero de color blanco que contrasta fuertemente con el fondo. El resultado es un afiche con un mensaje muy claro: desastre.

\footnotetext{
${ }^{3}$ Point of purchase. Se refiere a la publicidad en los cines, que son el punto en el que el consumidor
} compra el producto, en este caso una película. 


\subsubsection{Material audiovisual de Rescate suicida}

La productora tenía bastante material audiovisual; sin embargo, todo estaba en ruso. La estrategia consistía en presentar la película solo en formato doblado, así que, a pesar de tener spots ya armados, se prepararon 2 spots nuevos de 10 y 15 segundos para pauta en televisión y pantallas digitales, a partir del avance, que era el único material doblado disponible.

El doblaje del avance y de la película fue realizado y cubierto por el distribuidor. Para toda la campaña, solo se usó la versión doblada del avance.

\subsection{Plan de medios}

Ambas películas destinaron el $42 \%$ del presupuesto total de marketing en la campaña de medios.

\subsubsection{TV Abierta}

\begin{tabular}{|c|c|c|c|}
\hline Película & Canal & Cantidad de spots & Exhibición \\
\hline Horizonte profundo & América Televisión & 18 & 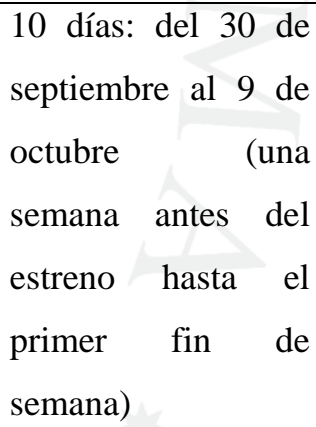 \\
\hline Rescate suicida & $\begin{array}{l}\text { Frecuencia Latina, } \\
\text { América Televisión }\end{array}$ & 30 & 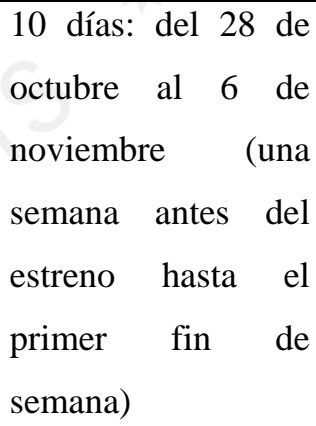 \\
\hline
\end{tabular}

La duración de la pauta y la anticipación de la misma al estreno fue igual en ambos casos; sin embargo, Rescate suicida tuvo más exhibición en televisión abierta que Horizonte profundo, ya que contó con exhibición en un canal adicional. No se optó 
por TV cable pagada debido a que la penetración aún es baja en el país y se decidió que la inversión no valdría la pena.

1.3.2. $\quad$ TV cable

\begin{tabular}{|c|c|c|c|}
\hline Película & Pauta & Cantidad de spots & Exhibición \\
\hline Horizonte profundo & No tuvo & 0 & \\
\hline Rescate suicida & $\begin{array}{l}\text { MTV, ESPN, } \\
\text { Discovery Channel, } \\
\text { ID, Cosmopolitan, } \\
\text { Casa Club, Animal } \\
\text { Planet (en Claro } \\
\text { TV) }\end{array}$ & 588 & $\begin{array}{l}14 \text { días: del } 24 \text { de } \\
\text { octubre al } 6 \text { de } \\
\text { noviembre ( } 10 \text { días } \\
\text { antes del estreno } \\
\text { hasta el primer fin } \\
\text { de semana) }\end{array}$ \\
\hline
\end{tabular}

Rescate suicida tuvo un acuerdo de canje $\mathrm{e}^{4}$ con Claro que le permitió tener pauta en TV cable de Claro.

\subsubsection{Periódicos}

\begin{tabular}{|l|l|l|}
\hline Película & Medio & Cantidad \\
\hline Horizonte profundo & La República y Líbero & 1 nota en cada diario por 5 días \\
\hline Rescate suicida & La República y Líbero & 1 nota en cada diario por 5 días \\
\hline
\end{tabular}

Ambas películas tuvieron un acuerdo de canje con La República que les permitió tener presencia en el diario a través de concursos por entradas a funciones de la película. Estos comenzaron a salir una semana antes del estreno.

\subsection{4. $\quad$ Radio}

\begin{tabular}{|l|l|l|l|}
\hline Película & Pauta & Cantidad de spots & Exhibición \\
\hline Rescate suicida & Radio Moda & 10 & $\begin{array}{l}\text { 8 días: del 24 al 28 } \\
\text { de octubre (10 a 5 } \\
\text { días antes del } \\
\text { estreno) }\end{array}$ \\
\hline Horizonte profundo & Radio Moda & 10 & $\begin{array}{l}\text { Del 28 de } \\
\text { septiembre al 4 de } \\
\text { octubre (8 a 2 días } \\
\text { antes del estreno) }\end{array}$ \\
\hline
\end{tabular}

\footnotetext{
${ }^{4}$ Por canje nos referimos a que no hay una compra de pauta, pero sí un intercambio de bienes. En este caso, fue una función en preestreno por una pauta en TV cable.
} 
Ambas películas tuvieron un acuerdo de canje con Radio Moda para tener spots al aire en los días previos al estreno.

1.3.5. Vía pública

\begin{tabular}{|c|c|c|c|c|}
\hline Elemento & $\begin{array}{l}\text { Horizonte } \\
\text { profundo }\end{array}$ & Exhibición & Rescate suicida & Exhibición \\
\hline $\begin{array}{l}\text { Vallas en el } \\
\text { Metro de Lima }\end{array}$ & 13 & $\begin{array}{l}14 \text { días: del } 26 \\
\text { de septiembre } \\
\text { al } 9 \text { de octubre }\end{array}$ & 13 vallas & $\begin{array}{l}3 \text { días: del } 24 \text { al } \\
27 \text { de octubre }\end{array}$ \\
\hline $\begin{array}{l}\text { Pantallas } \\
\text { digitales en el } \\
\text { Metro de Lima }\end{array}$ & 0 & & $\begin{array}{ll}\text { Mix } & \text { de } \\
\text { pantallas } & \\
\text { digitales } & \text { en } \\
\text { estaciones } & \end{array}$ & $\begin{array}{l}14 \text { días: del } 24 \\
\text { de octubre al } 6 \\
\text { de noviembre }\end{array}$ \\
\hline Vallas simples & 0 & & 7 & $\begin{array}{l}9 \text { días: del } 29 \\
\text { de octubre al } 6 \\
\text { de noviembre }\end{array}$ \\
\hline $\begin{array}{l}\text { Centros } \\
\text { comerciales }\end{array}$ & 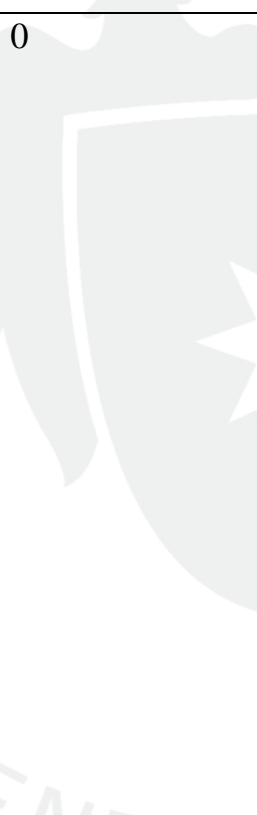 & & $\begin{array}{l}\text { Combo de } \\
\text { pantallas } \\
\text { digitales, vallas } \\
\text { y videowalls en } \\
\text { centros } \\
\text { comerciales } \\
\text { (Plaza Lima } \\
\text { Norte, Plaza } \\
\text { Lima Sur, } \\
\text { Royal Plaza, } \\
\text { Parque Cánepa, } \\
\text { Mall Aventura, } \\
\text { Mall del Sur) }\end{array}$ & $\begin{array}{l}14 \text { días: del } 24 \\
\text { de octubre al } 6 \\
\text { de noviembre }\end{array}$ \\
\hline Real Plaza & $\begin{array}{l}5 \text { displays } \mathrm{y} \\
\text { videowalls }\end{array}$ & $\begin{array}{l}18 \text { días: del } 26 \\
\text { de septiembre } \\
\text { al } 13 \text { de octubre }\end{array}$ & 5 displays & $\begin{array}{l}21 \text { días: del } 20 \\
\text { de octubre al } 10 \\
\text { de noviembre }\end{array}$ \\
\hline iWalls & 51 & $\begin{array}{l}14 \text { días: del } 26 \\
\text { de septiembre } \\
\text { al } 9 \text { de octubre }\end{array}$ & 0 & \\
\hline
\end{tabular}

Aquí está la diferencia más grande entre ambas campañas de marketing. Para Horizonte profundo se optó por una combinación entre vallas en el Metro de Lima y 
iWalls en centros comerciales. Para Rescate suicida, en lugar de los iWalls se eligieron unas pantallas digitales exteriores en centros comerciales clave (Mall del Sur, Plaza Lima Norte y Plaza Lima Sur). La intención acerca de la duración de la pauta para ambas películas era que comenzara diez días antes del estreno y se mantuviera durante el primer fin de semana. Esto no se logró para Rescate suicida porque, por error del proveedor, se retiraron las vallas del Metro de Lima antes de tiempo. Por este motivo, se obtuvo un bonificado de vallas normales y pantallas digitales en el Metro de Lima y en otros centros comerciales. Esto llevó a que Rescate suicida, a pesar de tener un tiempo de exhibición trunco, tuvo un alcance superior gracias a la mayor cantidad de pantallas digitales y a la presencia en la mayoría de centros comerciales de Lima.

La elección del Metro de Lima se debe a que un gran bloque del público $\mathrm{C}$ utiliza este medio de transporte con frecuencia diaria, lo cual permite una buena exhibición. Para otras películas de perfil similar, la distribuidora ha optado por usar los espacios del Metro de Lima. Por otro lado, los iWalls están presentes en centros comerciales A, B y C. Para Horizonte profundo se prefirió usar los iWalls porque llegaban a su público objetivo. Sin embargo, la bonificación de pantallas digitales del Metro de Lima y de centros comerciales tuvo mucha mejor exhibición y parece haber funcionado mucho mejor que solo comunicando en iWalls.

Ambas películas lograron presencia en Real Plaza gracias a un canje, por el cual se obtuvieron casi tres semanas de exhibición de displays. Por cuestiones de disponibilidad y negociación, Horizonte profundo pudo tener adicionalmente presencia en los videowalls de los patios de comidas de los centros comerciales.

Vía pública de Horizonte profundo

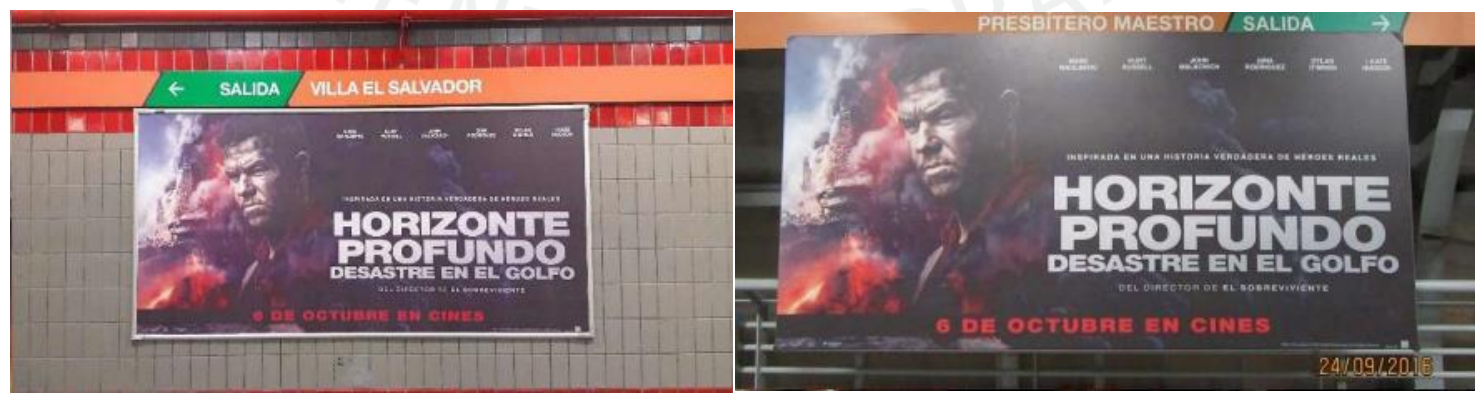

Vallas en el Metro de Lima 

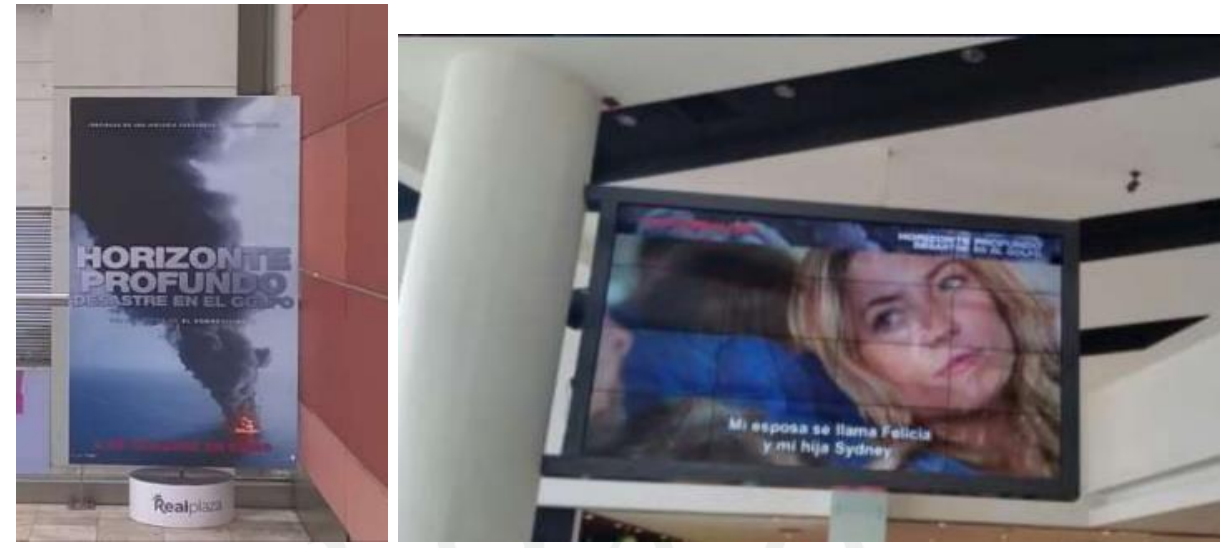

Displays y videowalls en Real Plaza
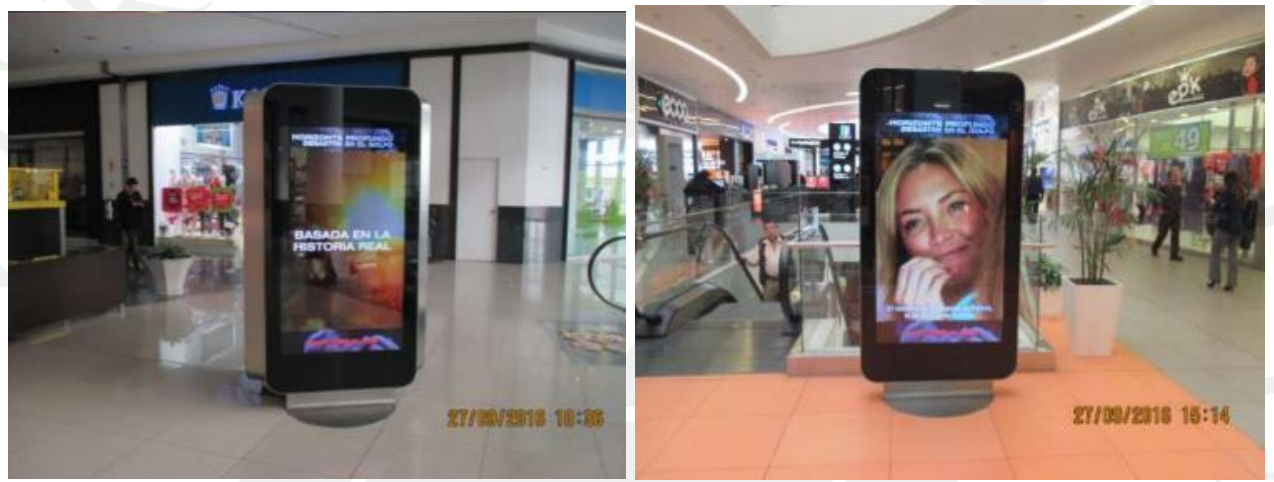

iWalls

Vía pública de Rescate suicida
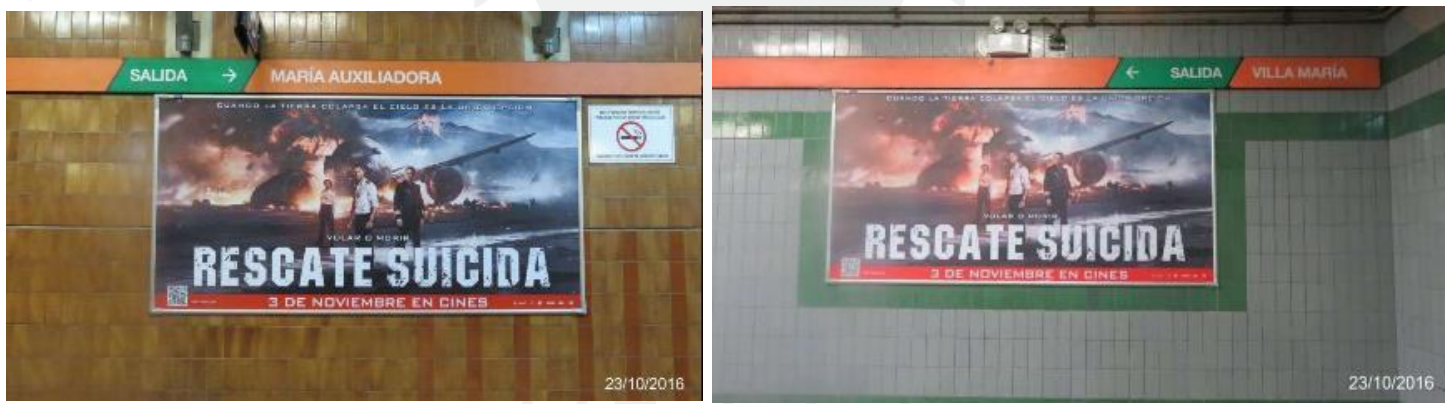

Vallas en el Metro de Lima 

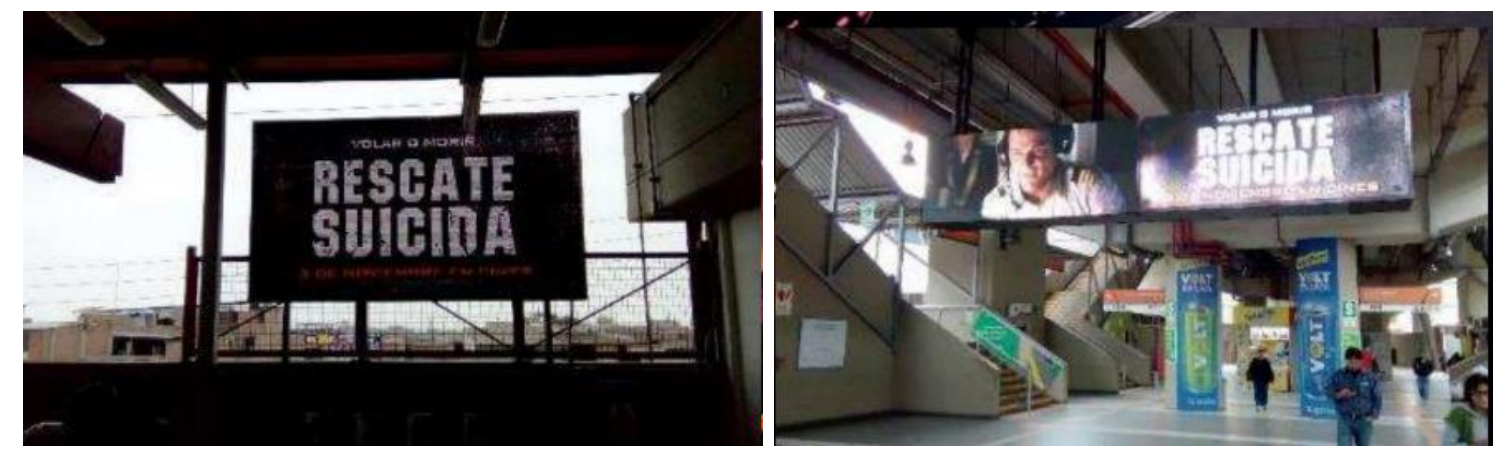

Pantallas digitales en el Metro de Lima

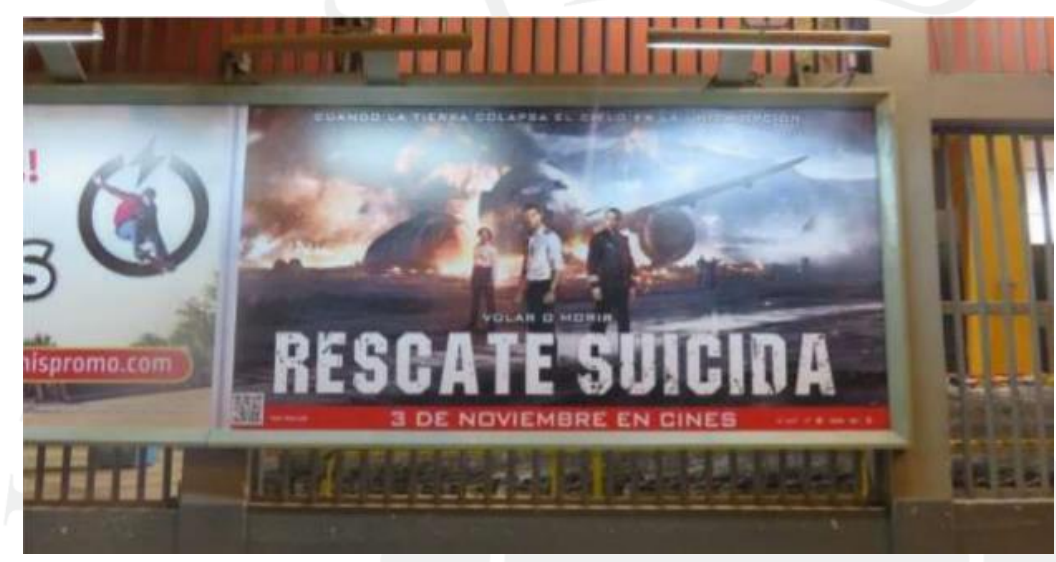

Vallas simples
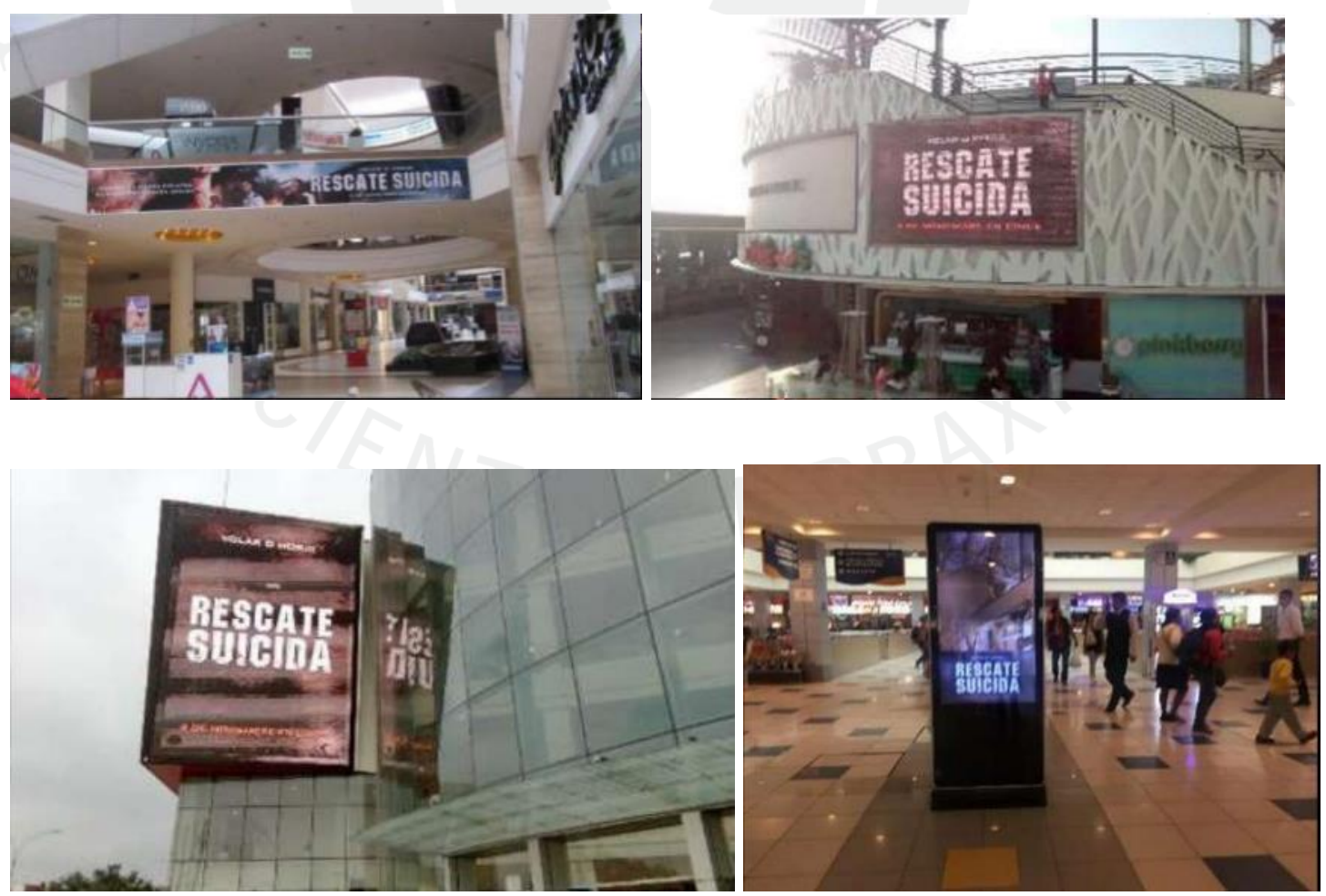
Vallas y pantallas en centros comerciales
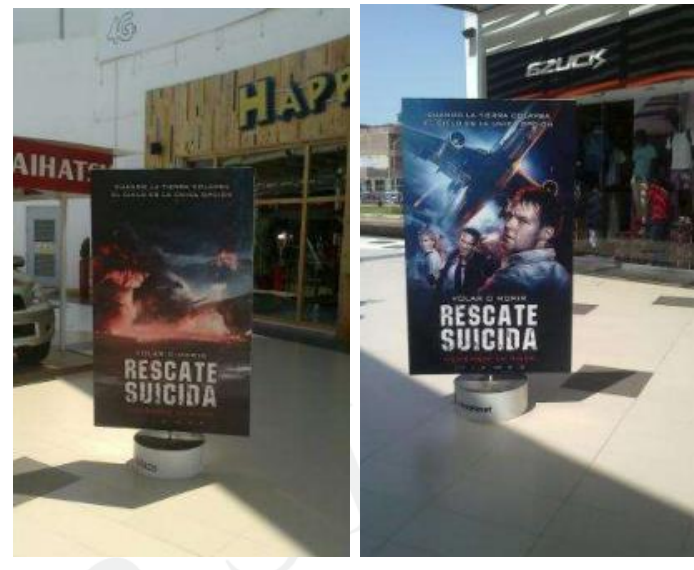

Displays en Real Plaza

\subsection{POP (Publicidad en cines)}

Rescate suicida destinó $38 \%$ del presupuesto total de marketing en POP, mientras que Horizonte profundo empleó el $33 \%$.

\begin{tabular}{|c|c|c|c|c|}
\hline Elemento & Horizonte profundo & Fecha & Rescate suicida & Fecha \\
\hline Pósteres & 300 modelo único & $\begin{array}{l}15 / 08 / 16- \\
7 \text { semanas } \\
\text { antes del } \\
\text { estreno }\end{array}$ & 300 modelo único & $\begin{array}{l}29 / 09 / 16- \\
8 \text { semanas } \\
\text { antes del } \\
\text { estreno }\end{array}$ \\
\hline Banners & 8 & $\begin{array}{l}29 / 08 / 16- \\
5 \text { semanas } \\
\text { antes del } \\
\text { estreno }\end{array}$ & 9 & $\begin{array}{l}29 / 09 / 16- \\
8 \text { semanas } \\
\text { antes del } \\
\text { estreno }\end{array}$ \\
\hline Standees & $\begin{array}{l}4 \text { standees especiales } \\
8 \text { standees tradicionales }\end{array}$ & $\begin{array}{l}05 / 09 / 16- \\
4 \text { semanas } \\
\text { antes del } \\
\text { estreno }\end{array}$ & 9 standees estrechos & $\begin{array}{l}03 / 10 / 16- \\
7 \text { semanas } \\
\text { antes del } \\
\text { estreno }\end{array}$ \\
\hline $\begin{array}{l}\text { Auto- } \\
\text { adhesivos }\end{array}$ & 3 rectangulares & $\begin{array}{l}12 / 09 / 16- \\
3 \text { semanas } \\
\text { antes del } \\
\text { estreno }\end{array}$ & 3 con troquel & $\begin{array}{l}10 / 10 / 16- \\
6 \text { semanas } \\
\text { antes del } \\
\text { estreno }\end{array}$ \\
\hline $\begin{array}{l}\text { Banners en } \\
\text { cortafilas }\end{array}$ & Cineplanet: 7 & $\begin{array}{l}29 / 08 / 16- \\
5 \text { semanas } \\
\text { antes del } \\
\text { estreno }\end{array}$ & $\begin{array}{l}\text { Cineplanet: } 23 \\
\text { Cinemark } 12\end{array}$ & $\begin{array}{l}29 / 09 / 16- \\
8 \text { semanas } \\
\text { antes del } \\
\text { estreno }\end{array}$ \\
\hline Colgantes & 0 & & 10 & $\begin{array}{l}10 / 10 / 16- \\
6 \text { semanas } \\
\text { antes del } \\
\text { estreno }\end{array}$ \\
\hline $\begin{array}{l}\text { Ubicaciones } \\
\text { especiales } \\
\text { (banderolas } \\
\text { y viniles) }\end{array}$ & $\begin{array}{l}8 \text { (incluyendo } 1 \\
\text { banderola exterior) } \\
3 \text { cabinas de fotos en } \\
\text { Cineplanet }\end{array}$ & $\begin{array}{l}29 / 08 / 16- \\
5 \text { semanas } \\
\text { antes del } \\
\text { estreno }\end{array}$ & $\begin{array}{l}11 \text { (incluyendo } 1 \text { banderola } \\
\text { exterior) }\end{array}$ & $\begin{array}{l}29 / 09 / 16- \\
8 \text { semanas } \\
\text { antes del } \\
\text { estreno }\end{array}$ \\
\hline
\end{tabular}




\begin{tabular}{|l|l|l|l|l|}
\hline $\begin{array}{l}\text { Otros } \\
\text { cargos }\end{array}$ & $\begin{array}{l}\text { Alquiler de espacios } \\
\text { Diseño gráfico }\end{array}$ & $\begin{array}{l}\text { Alquiler de espacios } \\
\text { Diseño gráfico }\end{array}$ & \\
\hline
\end{tabular}

La diferencia más importante entre estas campañas similares estuvo en los standees. En Horizonte profundo se invirtió en hacer standees especiales, es decir, con formas especiales recortadas y de mayor impacto. Estos se enviaron a los cines más importantes. Mientras que, para Rescate suicida, solo se hicieron standees simples y pequeños.

Rescate suicida también tuvo más presencia en banners en cortafilas, que son un sistema exclusivo de BF Distribution en Cineplanet y compartido en Cinemark. Se considera un espacio clave debido a los cortafilas que se colocan en boleterías y confiterías, las zonas más transitadas en los cines.

Además, se hicieron unos colgantes de Rescate suicida para los cines populares con poco espacio, ya que los artes de personajes lo permitían.

El POP de Rescate suicida fue más simple en estilo y costos. Sin embargo, parece que fue más efectivo que los elementos de alto impacto de Horizonte profundo.

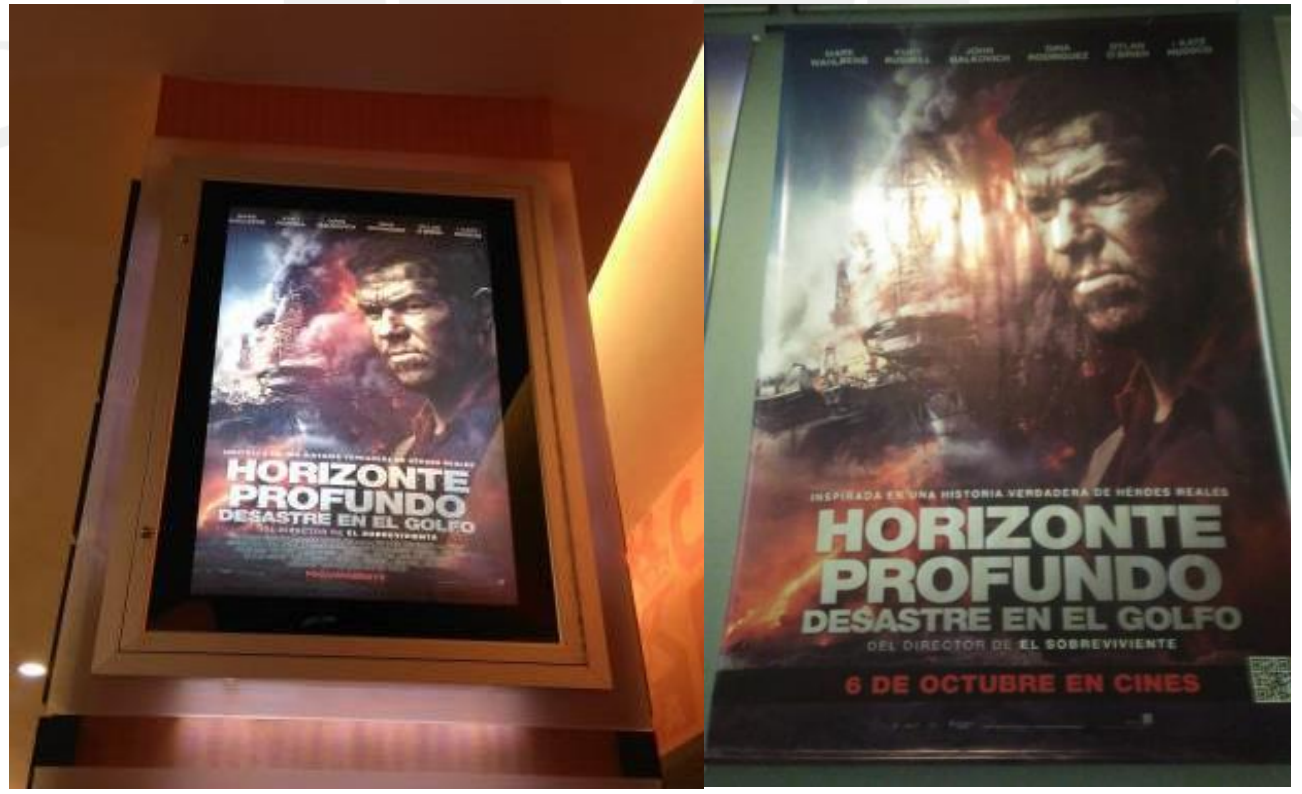

Póster y banner de Horizonte profundo 


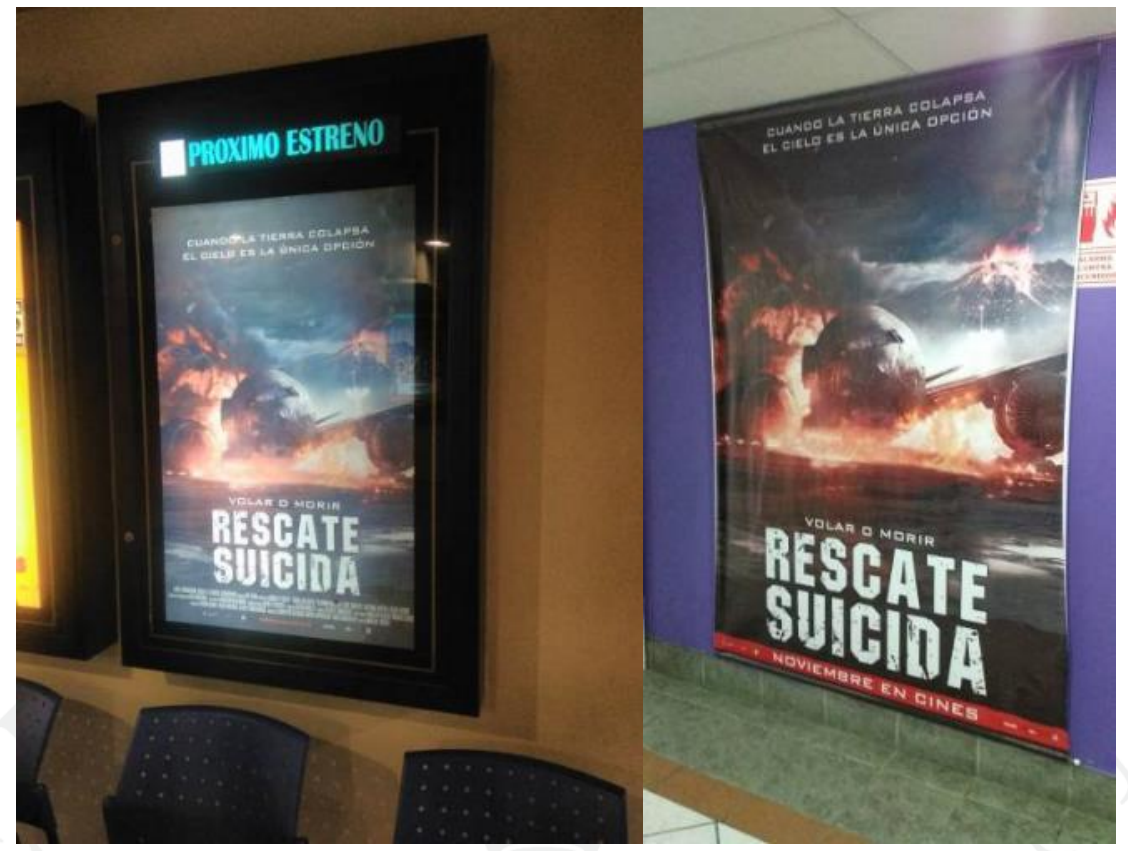

Póster y banner de Rescate suicida

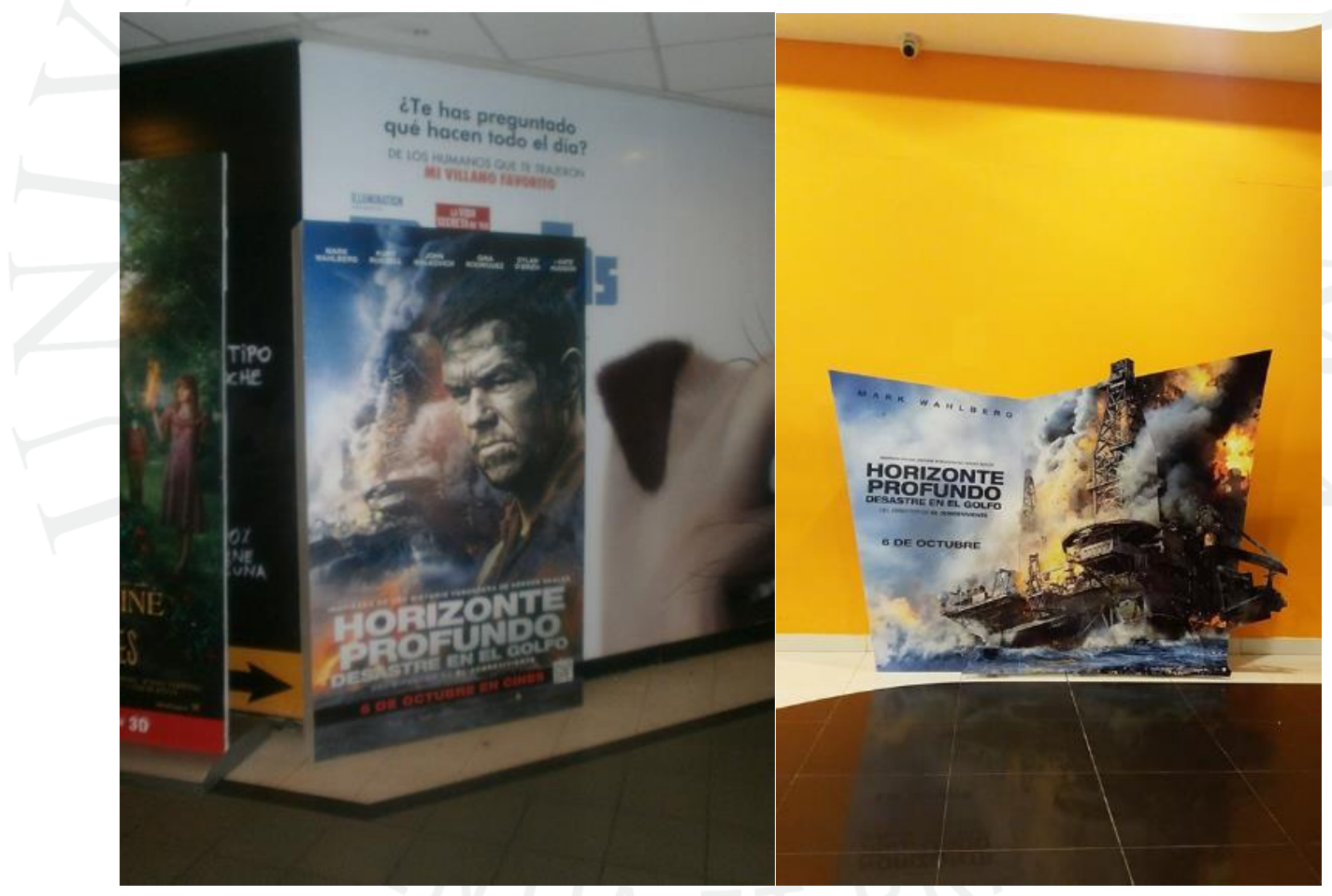

Standees de Horizonte profundo 


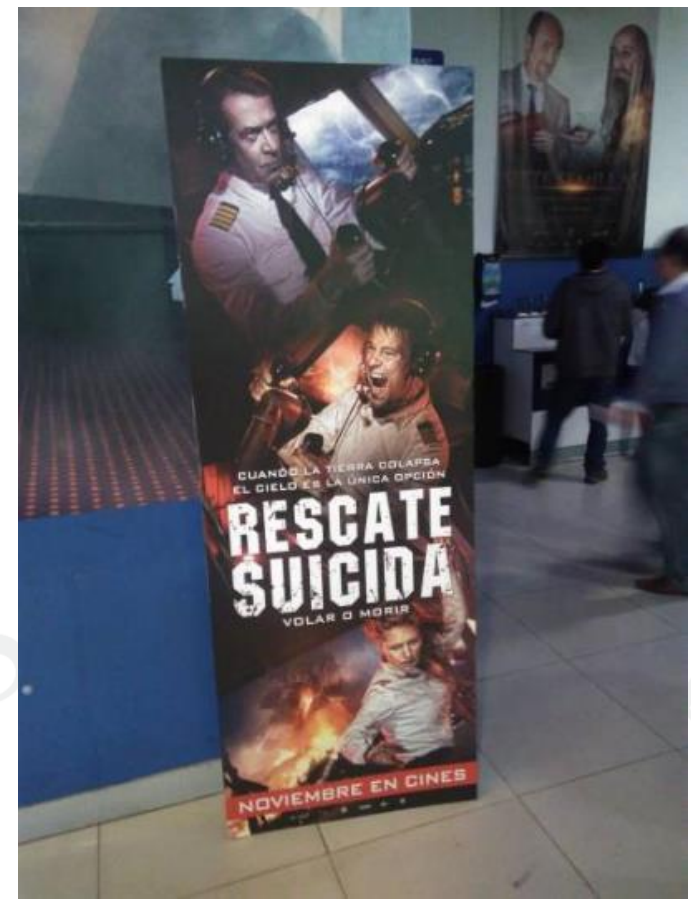

Standees de Rescate suicida

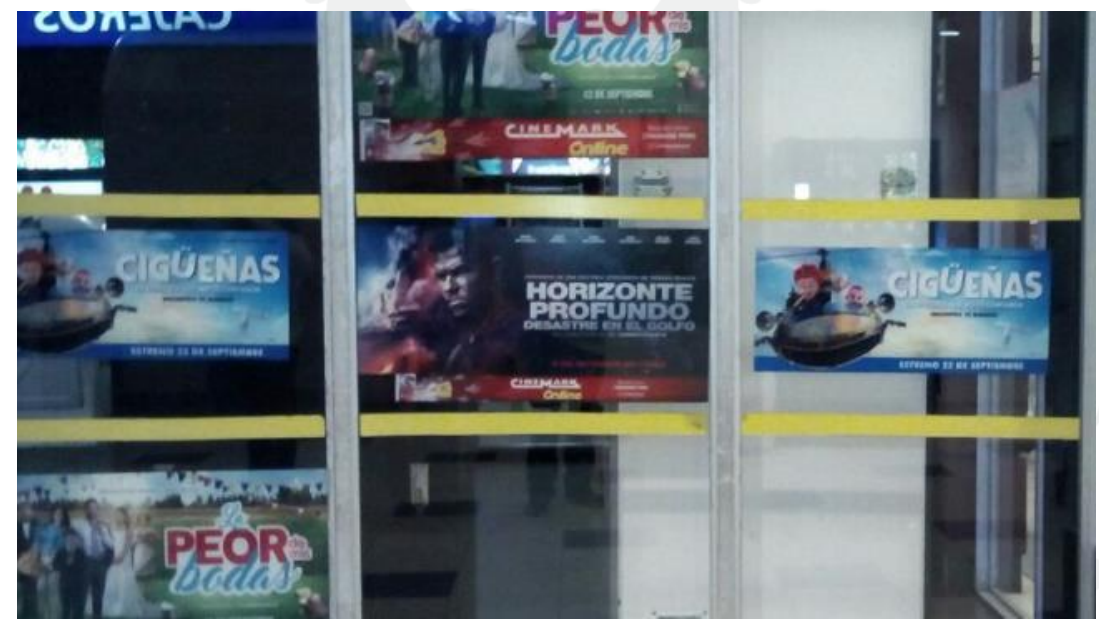

Adhesivos de vitrina de Horizonte profundo

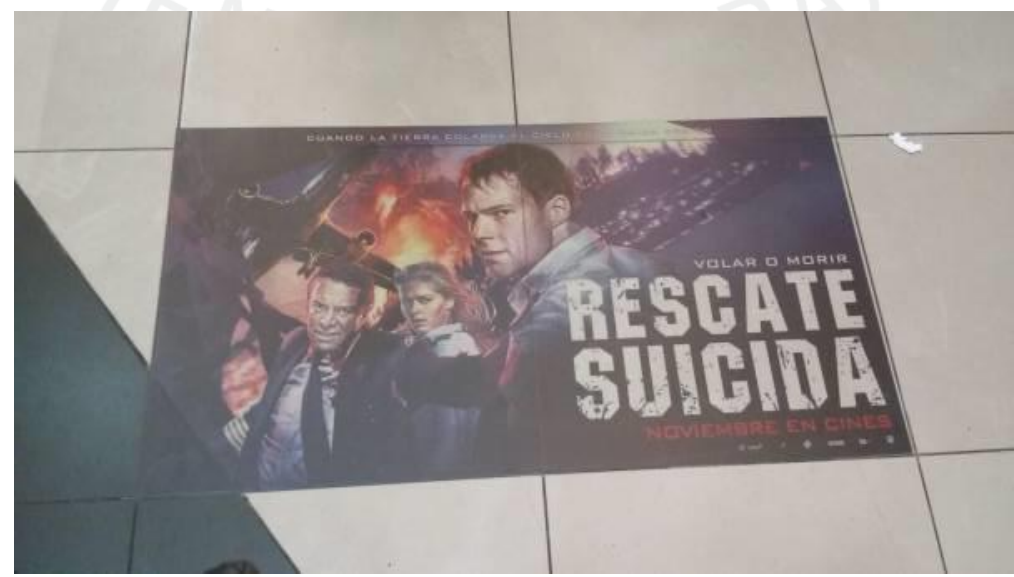


Adhesivos de piso de Rescate suicida

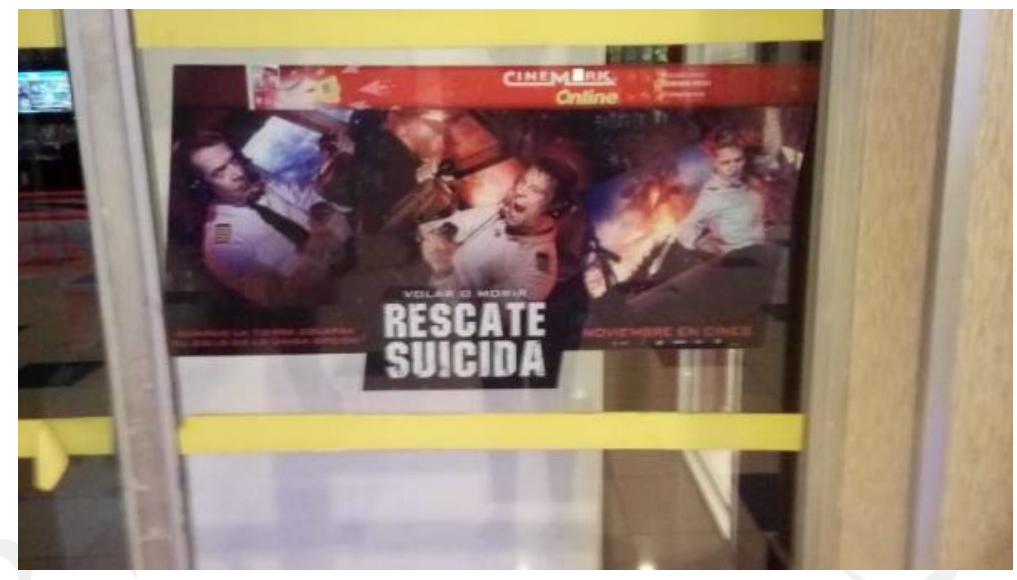

Adhesivos de vitrina de Rescate suicida

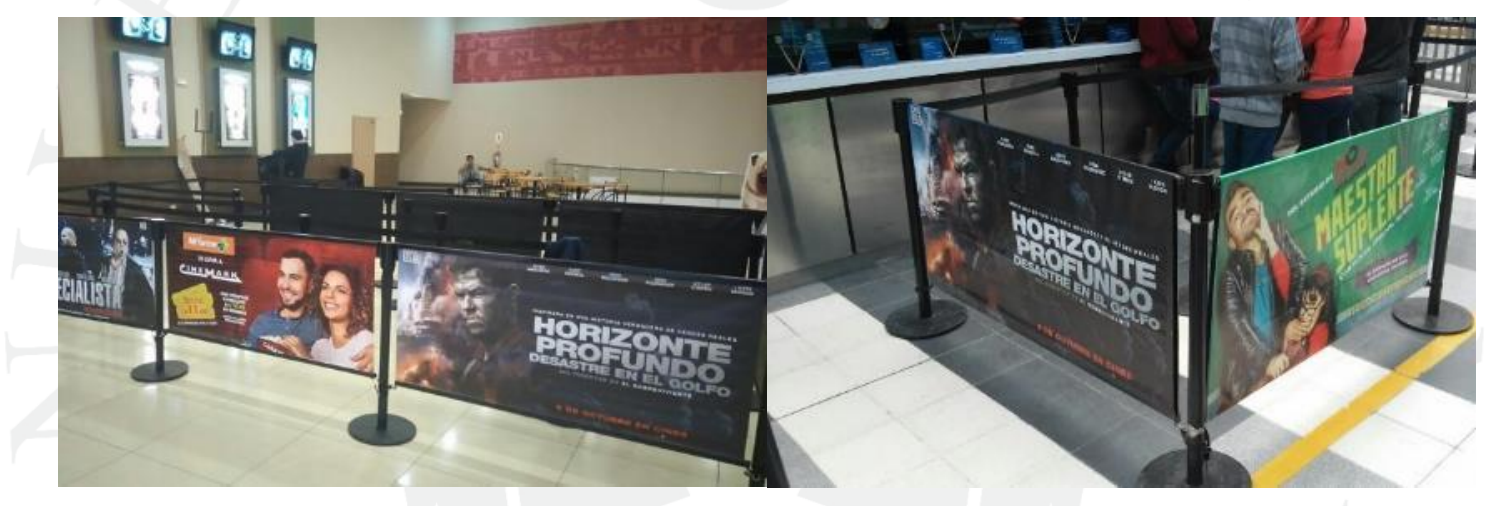

Cortafilas en Cinemark y Cineplanet de Horizonte profundo

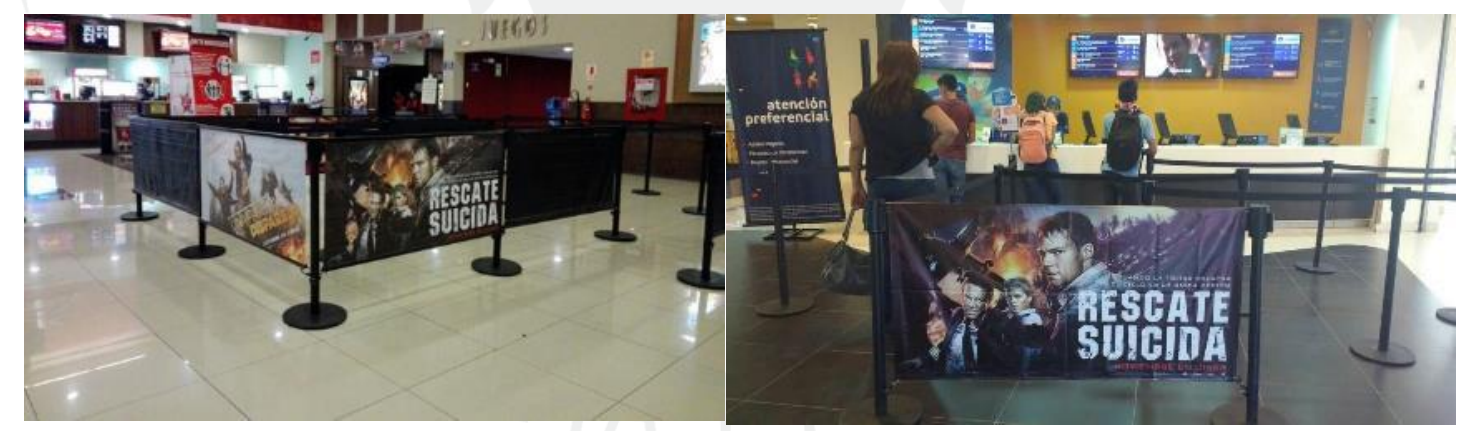

Cortafilas de Rescate suicida 


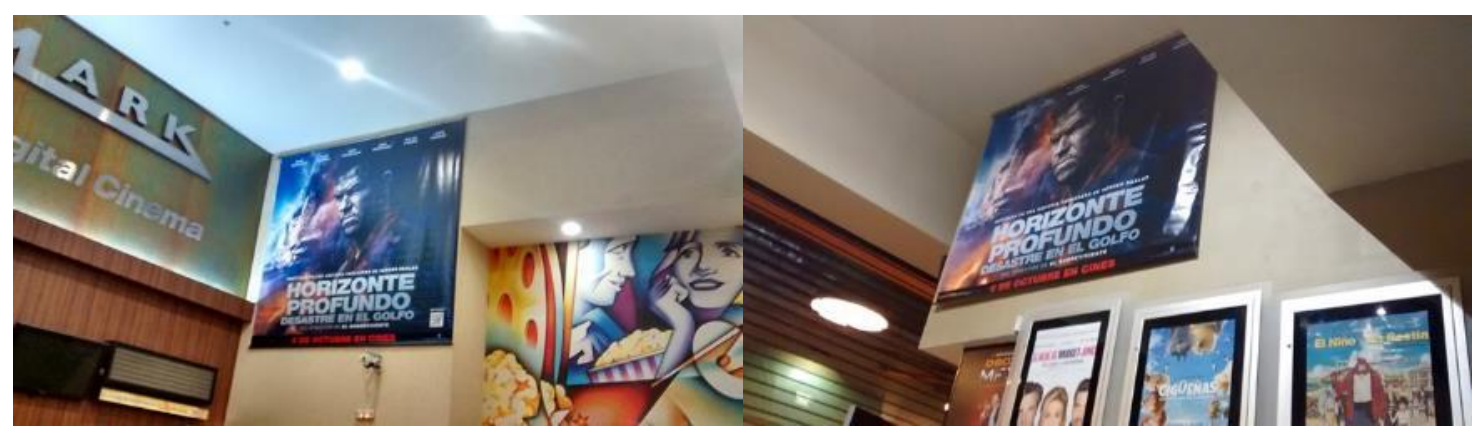

Banderolas en Cinemark Angamos y Jockey Plaza

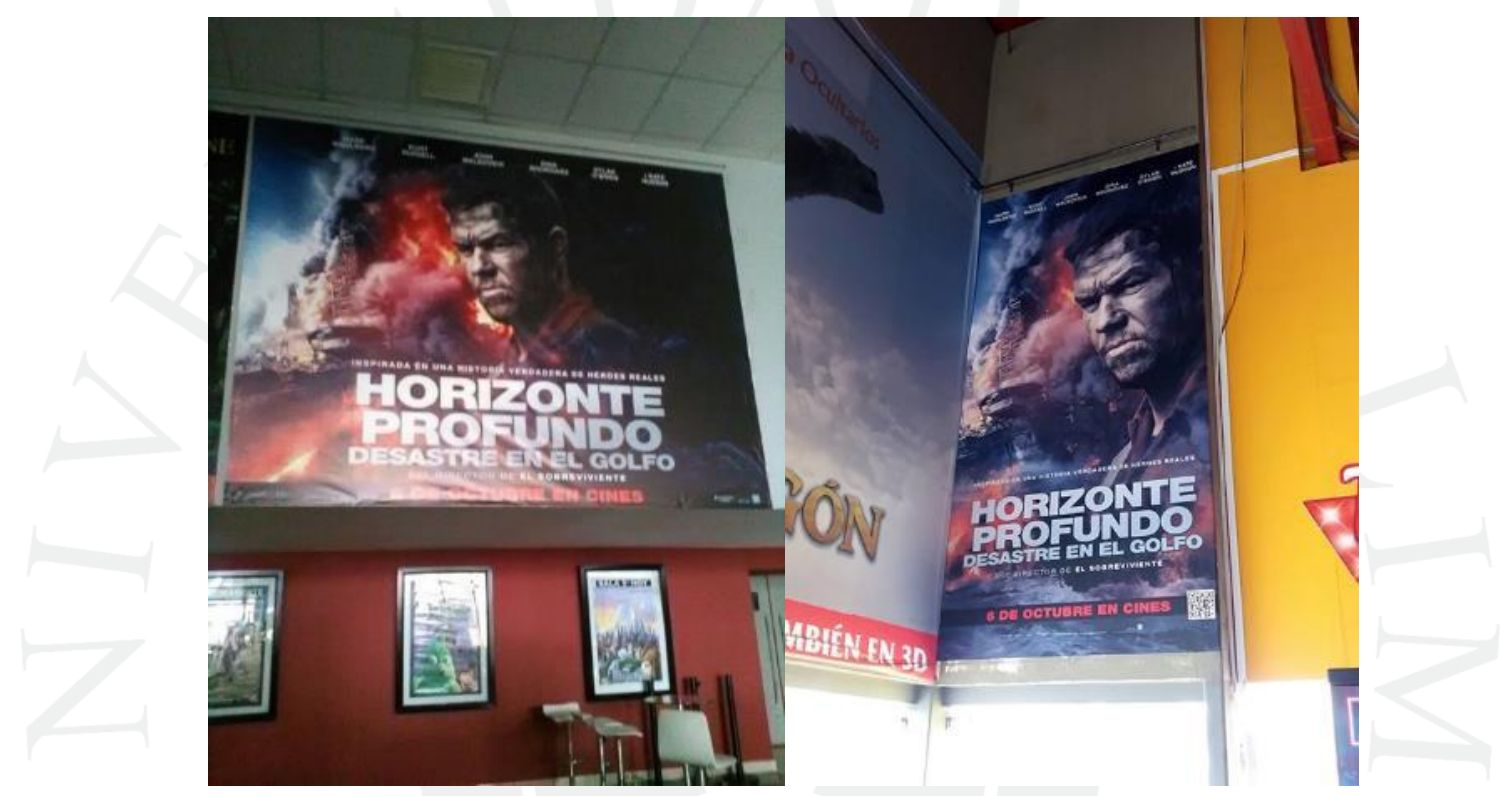

Espacios en UVK Caminos del Inca y Cineplanet Risso

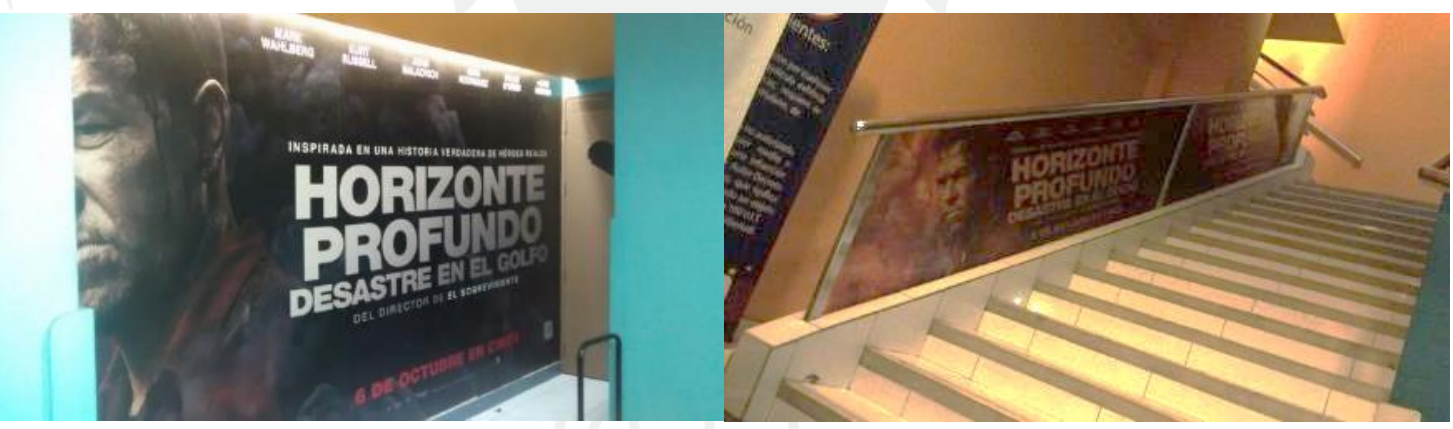

Viniles en Cineplanet La Molina y Cineplanet San Miguel 


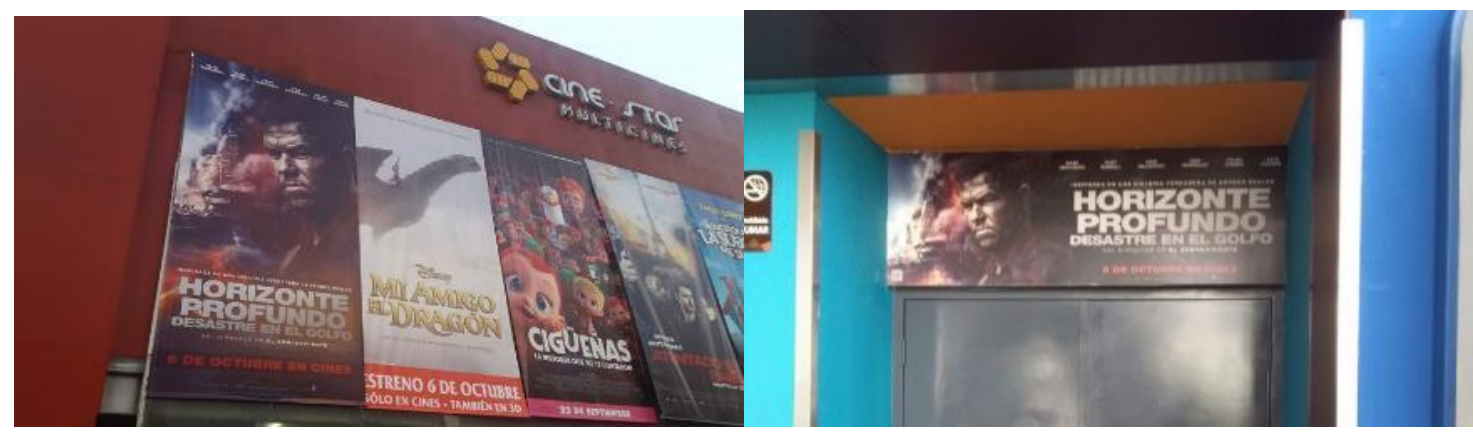

Banderola exterior en Cine Star Breña y vinil en Cineplanet Alcázar

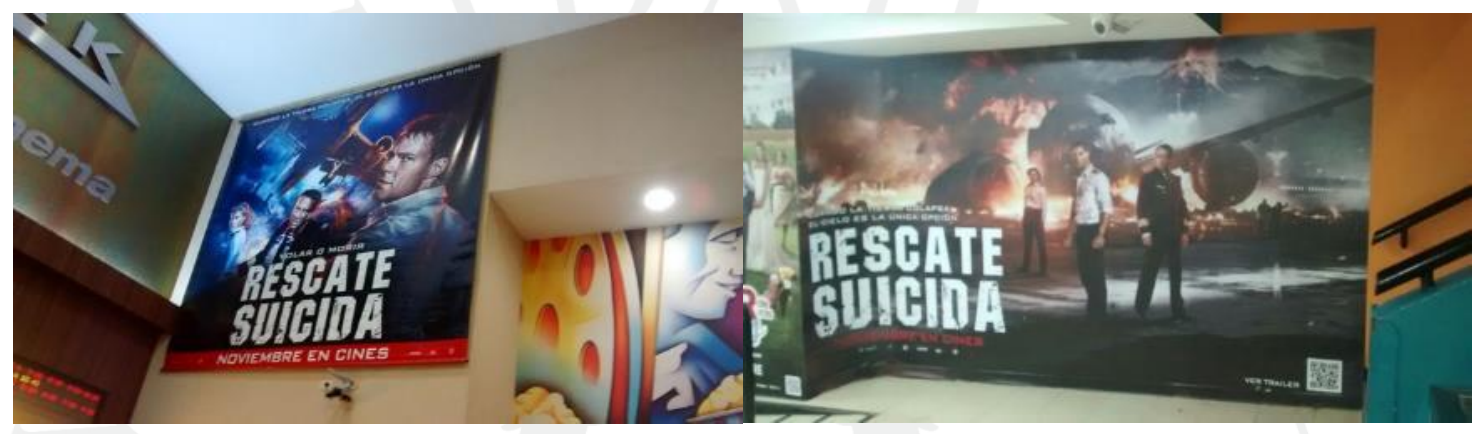

Banderola en Cinemark Angamos y Vinil en Cineplanet Centro

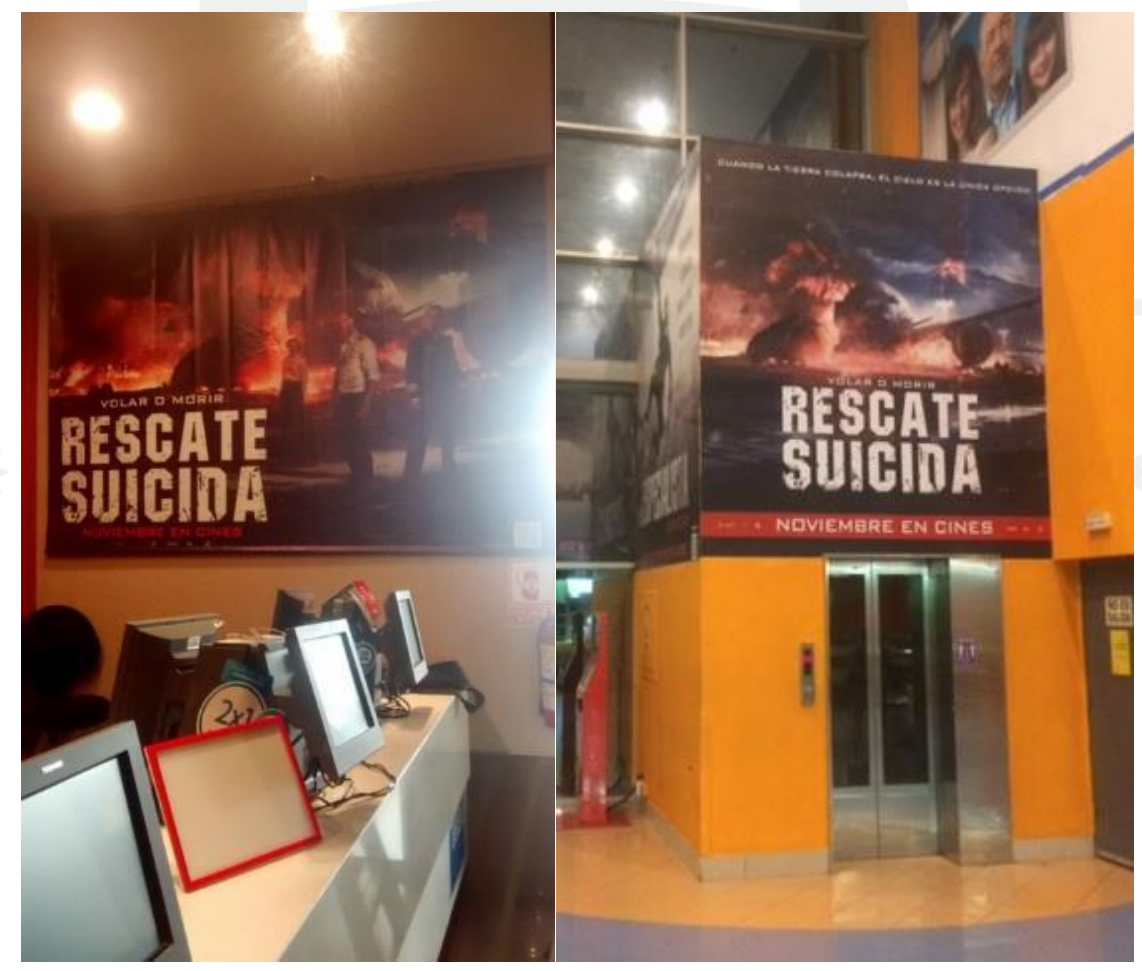

Banderola en Cinemark Megaplaza y Vinil en Cineplanet Centro Cívico 


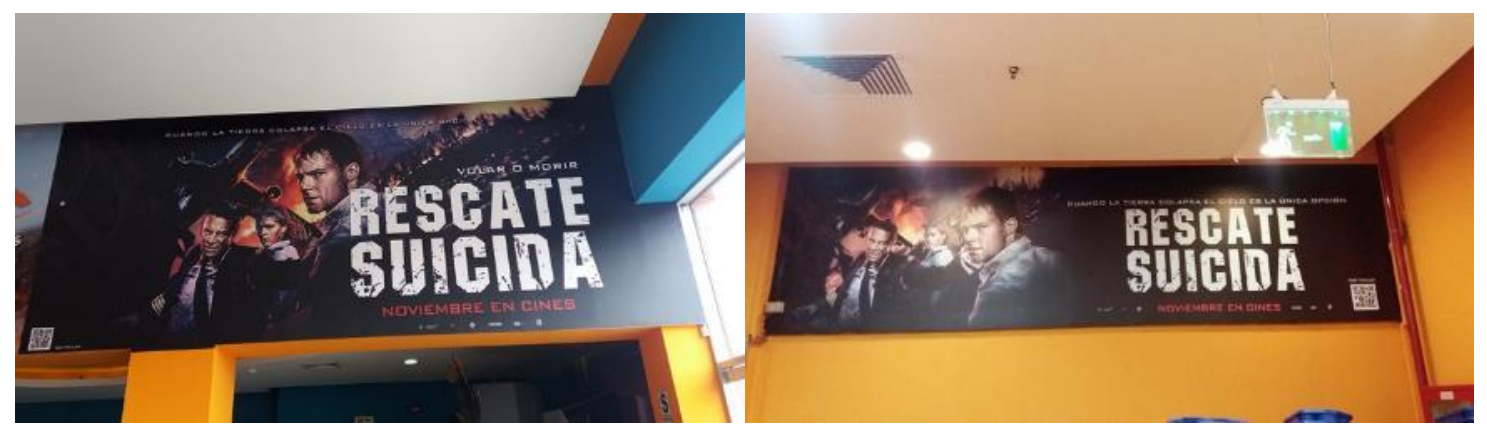

Viniles en Cineplanet Pro y Cineplanet Risso

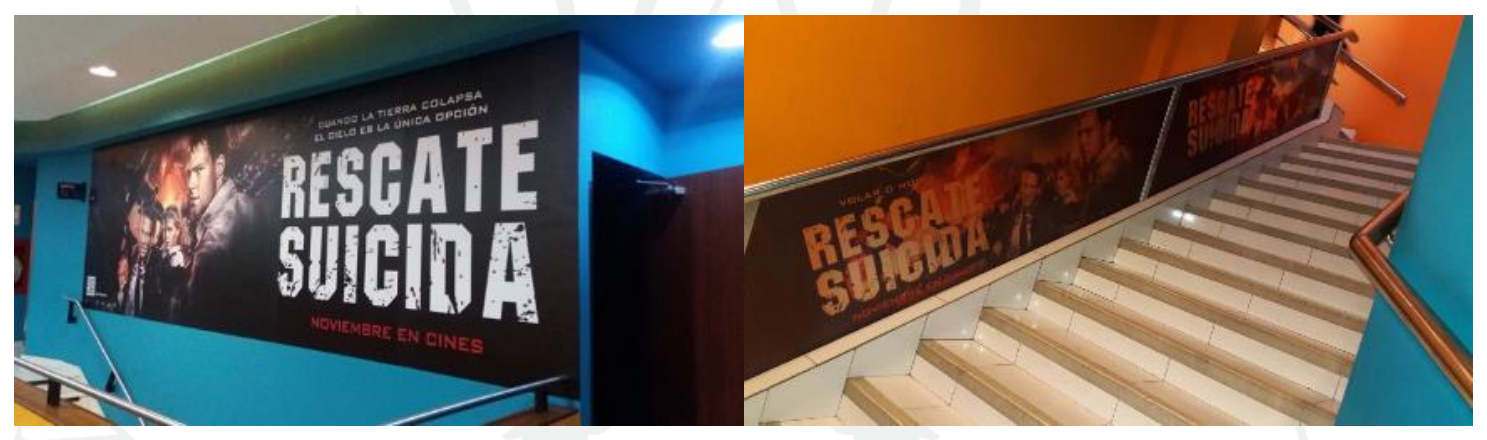

Viniles en Cineplanet Salaverry y Cineplanet San Miguel

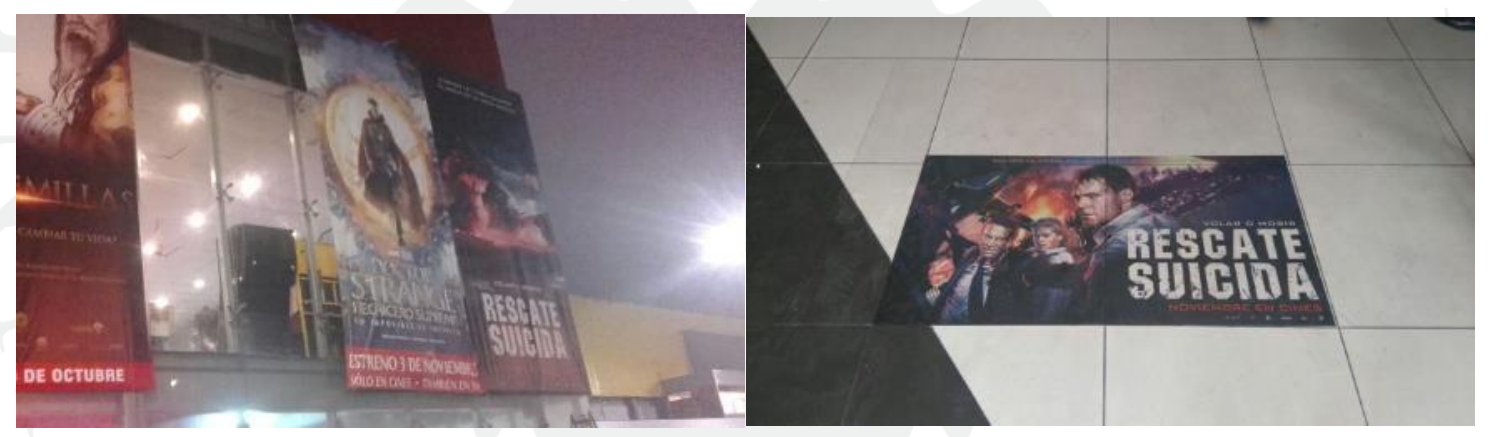

Banderola Cine Star Breña y Adhesivo grande en Cine Star Excélsior

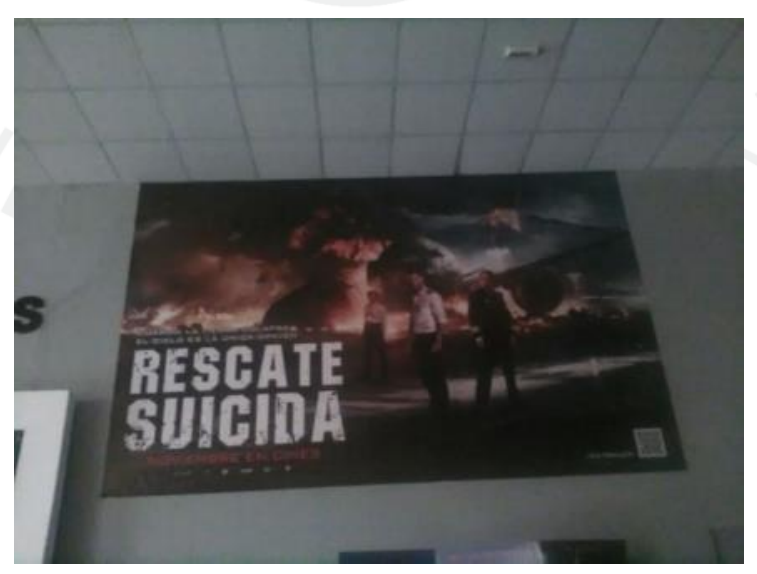

Banderola en UVK Caminos del Inca 


\subsection{Promociones}

Para ambas películas, la estrategia de alianzas promocionales fue la misma. Se buscó el mismo tipo de marcas y se consiguieron los mismos tratos. Pero Rescate suicida, al tener más acción que drama, también hizo posible una alianza con la tienda de videojuegos Next Level. El tipo de presencia en locales se hizo con jalavistas en caja, afiches o banners que comunicasen la película o la promoción entre la marca y la película. La presencia en redes sociales se dio con el avance del filme o con imágenes de la película y de la promoción entre la marca y la película. A cambio, se les ofreció estos beneficios:

- Pases libres: Para usarse solo en Cineplanet, siempre que la película estuviese en cartelera.

- Cupones 2x1: Vales de descuento por los que se pagaba una entrada a precio completo y entraban dos. Válidos solo en Cineplanet y para la película siempre que estuviera en cartelera.

- Invitaciones al preestreno: Función exclusiva previa al estreno cuyo ingreso era solo con invitación.

- Presencia en el preestreno: La marca podía tener su logo en las invitaciones y en un reel que se presentaba previamente al inicio de la película, así como un spot de 30 segundos. También podía tener un banner o módulo en el lobby o realizar una activación antes o después de la función.

Rescate suicida destinó 8,5\% del presupuesto total de marketing a promociones. A través de una negociación por entradas al preestreno local y entradas para ver la película, se tuvo presencia en locales y redes sociales de las marcas Bodytech (gimnasio), Cruz del Sur (empresa de transporte), Next Level (tienda de videojuegos) y Bruno Ferrini (zapatería).

Horizonte profundo destinó $7,5 \%$ del presupuesto general de marketing a promociones. A través de una negociación por entradas al preestreno local y entradas para ver la película, se tuvo presencia en locales y redes sociales de las marcas Bodytech (gimnasio), Cruz del Sur (empresa de transporte) y Bruno Ferrini (zapatería). 


\subsection{Redes sociales}

Ninguna de las películas tuvo inversión pagada en redes sociales, fuera del pago de una agencia digital que mueve las redes de la distribuidora. La campaña consistió en mover de manera orgánica el material de la película en las redes sociales de la distribuidora, y compartirlo en las de los exhibidores y socios promocionales.

\subsection{Prensa}

Ninguna de las películas tuvo oportunidades de prensa, como junkets o entrevistas exclusivas. Sin embargo, se consideró el pago de una agencia de prensa que movió notas de prensa a una base de datos de periodistas y medios. Solo en el caso de Horizonte profundo, hubo una función exclusiva para la prensa antes del estreno y materiales como featurettes y clips de la película.

2. Resultados de taquilla

Horizonte profundo se estrenó el 6 de octubre del 2016 en séptimo lugar, con 77.082 admisiones en 86 pantallas. Este fue su copiado en la semana de estreno:

\begin{tabular}{|l|c|}
\hline CINE & Horizonte profundo \\
\hline CINEMARK JOCKEY PLAZA & 1 sala \\
\hline CINEMARK SAN MIGUEL & 1 sala \\
\hline CINEMARK MEGAPLAZA & 1 sala \\
\hline CINEMARK OPEN PLAZA ANGAMOS & 1 sala \\
\hline CINEMARK PLAZA LIMA SUR & 1 sala \\
\hline CINEMARK BELLAVISTA & 1 sala \\
\hline CINEMARK AREQUIPA LAMBRAMANI & 1 sala \\
\hline CINEMARK AREQUIPA MAPA & 1 sala \\
\hline CINEMARK PIURA & 1 sala \\
\hline CINEMARK TRUJILLO & 2 funciones \\
\hline CINEMARK HUÁNUCO & 2 funciones \\
\hline CINEMARK CAJAMARCA & 1 sala \\
\hline & 1 sala \\
\hline CINEPLANET ALCÁZAR & \\
\hline CINEPLANET LA MOLINA & 1 sala \\
\hline CINEPLANET SAN MIGUEL & 1 sala \\
\hline CINEPLANET SAN MIGUEL II & 1 sala \\
\hline CINEPLANET CENTRO & 1 sala \\
\hline CINEPLANET PRIMAVERA & 2 funciones \\
\hline CINEPLANET NORTE & 1 sala \\
\hline CINEPLANET RISSO & 1 sala \\
\hline CINEPLANET COMAS & 1 sala \\
\hline CINEPLANET CENTRO CÍVICO & \\
\hline CINEPLANET SANTA CLARA & sala +1 sala prime \\
\hline CINEPLANET PRO & \\
\hline
\end{tabular}




\begin{tabular}{|c|c|}
\hline CINEPLANET PRIME SAN BORJA & 1 sala \\
\hline CINEPLANET SALAVERRY & 1 sala \\
\hline CINEPLANET VENTANILLA & 1 sala \\
\hline CINEPLANET BRASIL & 1 sala \\
\hline CINEPLANET GUARDIA CIVIL & 1 sala \\
\hline CINEPLANET MALL DEL SUR & 1 sala \\
\hline CINEPLANET AREQ OPEN & 1 sala \\
\hline CINEPLANET AREQ RP & 2 funciones \\
\hline CINEPLANET PIURA & 1 sala \\
\hline CINEPLANET CHICLAYO & 1 sala \\
\hline CINEPLANET TRUJ CENTRO & 1 sala \\
\hline \multicolumn{2}{|l|}{ CINEPLANET TRUJ REAL PLAZA } \\
\hline CINEPLANET HUANCAYO & 1 sala \\
\hline CINEPLANET JULIACA & 1 sala \\
\hline CINEPLANET TACNA & 1 sala \\
\hline CINEPLANET PUNO & 1 sala \\
\hline CINEPLANET HUÁNUCO REAL PLAZA & 1 sala \\
\hline CINEPLANET PIURA REAL PLAZA & 1 sala \\
\hline CINEPLANET CAJAMARCA & 1 sala \\
\hline CINEPLANET CUZCO & 1 sala \\
\hline CINEPLANET PUCALLPA & 1 sala \\
\hline PLAZA JESÚS MARÍA & 1 sala \\
\hline CINERAMA EL PACÍFICO & 1 sala \\
\hline CINERAMA CAJAMARCA & 1 sala \\
\hline CINERAMA MINKA & 1 sala \\
\hline \multicolumn{2}{|l|}{ CINERAMA ICA PLAZA DEL SOL } \\
\hline \multicolumn{2}{|l|}{ CINERAMA TARAPOTO } \\
\hline CINERAMA ICA EL QUINDE & 1 sala \\
\hline CINERAMA CHIMBOTE MEGA EXPRESS & 1 sala \\
\hline CINERAMA MOYOBAMBA & \\
\hline \multicolumn{2}{|l|}{ CINERAMA CUZCO } \\
\hline CINÉPOLIS LIMA NORTE & 1 sala \\
\hline CINÉPOLIS SANTA ANITA & 1 sala +2 funciones \\
\hline \multicolumn{2}{|l|}{ CINÉPOLIS PUCALLPA } \\
\hline CINÉPOLIS AREQUIPA & 1 sala \\
\hline STAR EXCÉLSIOR & 1 sala \\
\hline STAR SUR & 1 sala \\
\hline STAR METRO SAN JUAN & 1 sala \\
\hline STAR BREÑA & 1 sala \\
\hline STAR METRO UNI & 1 sala \\
\hline STAR PUCALLPA & 1 sala \\
\hline STAR TARAPOTO & 1 sala \\
\hline STAR TUMBES & 1 sala \\
\hline STAR TACNA & 1 sala \\
\hline STAR MOQUEGUA & 2 funciones \\
\hline STAR LAS AMÉRICAS & 1 sala \\
\hline STAR COMAS & 3 funciones \\
\hline STAR PORTEÑO & 1 sala \\
\hline STAR AVIACIÓN & 2 funciones \\
\hline STAR BENAVIDES & 2 funciones \\
\hline STAR IQUITOS & 1 sala \\
\hline STAR BAHÍA CHIMBOTE & 2 funciones \\
\hline STAR SULLANA & 1 sala \\
\hline
\end{tabular}




\begin{tabular}{|l|c|} 
MOVIETIME MEGA PLAZA CHORRILLOS & 1 sala \\
\hline MOVIETIME MEGA PLAZA VILLA EL SALVADOR & 2 funciones \\
\hline MOVIETIME MEGA PLAZA CHINCHA & 3 funciones \\
\hline MOVIETIME CAÑETE & 3 funciones \\
\hline MOVIETIME BARRANCA & 1 sala \\
\hline MOVIETIME PISCO & 3 funciones \\
\hline MOVIETIME JAÉN & 1 sala \\
\hline & \\
\hline UVK ASIA & 1 sala +1 función \\
\hline UVK LARCOMAR & 1 sala \\
\hline UVK CAMINOS DEL INCA & 1 sala \\
\hline UVK PLATINO BASADRE & 1 sala \\
\hline UVK SAN MARTÍN & 3 funciones \\
\hline UVK EL AGUSTINO & 2 funciones \\
\hline UVK HUACHO & 2 funciones \\
\hline UVK ICA & 1 sala \\
\hline UVK PIURA & \\
\hline
\end{tabular}

El panorama competitivo fue así:

\begin{tabular}{|l|l|l|l|l|l|l|}
\hline & Película & Género & Distribuidor & Sem. & Pant. & Adm. Sem. \\
\hline 1 & Mi amigo el dragón & Familiar & Cinecolor & $\mathbf{1}$ & $\mathbf{9 1}$ & $\mathbf{1 9 1 5 7 1}$ \\
\hline 2 & La peor de mis bodas & Comedia & BF Cineplex & 3 & 87 & 132770 \\
\hline 3 & El especialista: La resurrección & Acción & BF Cineplex & 2 & 75 & 113270 \\
\hline 4 & Cigüeñas & Animación & $\begin{array}{l}\text { New Century } \\
\text { Films }\end{array}$ & 3 & 70 & 106847 \\
\hline 5 & $\begin{array}{l}\text { Miss Peregrine y los niños } \\
\text { peculiares }\end{array}$ & Familiar & $\begin{array}{l}\text { New Century } \\
\text { Films }\end{array}$ & 2 & 88 & 101893 \\
\hline 6 & Todos los hombres son iguales & Comedia & Tondero & $\mathbf{1}$ & $\mathbf{7 5}$ & $\mathbf{8 3 7 2 2}$ \\
\hline 7 & Horizonte profundo & Acción & BF Cineplex & $\mathbf{1}$ & $\mathbf{8 6}$ & $\mathbf{7 7 0 8 2}$ \\
\hline 8 & Margarita & Familiar & BF Cineplex & 5 & 24 & 20890 \\
\hline 9 & El bebé de Bridget Jones & Comedia & UIP & 4 & 16 & 19270 \\
\hline 10 & Las posesiones de Tess & Terror & Mundo Films & $\mathbf{1}$ & $\mathbf{2 3}$ & $\mathbf{1 7 6 4 3}$ \\
\hline 11 & La bruja de Blair & Terror & BF Cineplex & 4 & 11 & 8693 \\
\hline 12 & Un secreto entre nosotros & Drama & Delta & $\mathbf{1}$ & $\mathbf{1 3}$ & $\mathbf{7 4 2 5}$ \\
\hline 13 & Visiones extrañas & Terror & Delta & 2 & 5 & 3755 \\
\hline 14 & Atentado en París & Acción & Delta & 4 & 3 & 2472 \\
\hline 15 & Un juego sin reglas & Acción & BF Cineplex & 6 & 2 & 1917 \\
\hline 16 & Mente implacable & Acción & Star Films & 3 & 2 & 1791 \\
\hline 15 & Los siete magníficos & Acción & Andes & 3 & 2 & 1593 \\
\hline 18 & De-Mentes Maestras & Comedia & Andes & 2 & 2 & 1136 \\
\hline 19 & La vida secreta de tus mascotas & Animación & UIP & 10 & 3 & 520 \\
\hline 20 & Un traidor entre nosotros & Suspenso & Diamond & 2 & 2 & 393 \\
\hline 21 & Max Steel Equipo Turbo & Animación & Independiente & 2 & 9 & 328 \\
\hline 22 & Bienvenidos a Monster High & Animación & Independiente & $\mathbf{1}$ & $\mathbf{9}$ & $\mathbf{2 7 5}$ \\
\hline 23 & Oddball y sus pingüinos & Familiar & Star Films & 2 & 1 & 219 \\
\hline 24 & El bosque de Karadima & Drama & Independiente & 2 & 1 & 157 \\
\hline 25 & El choque de dos mundos & Documental & Cinecolor & Pre & 1 & 117 \\
\hline & & & & \\
\hline
\end{tabular}

Fuente: Rentrak 
Se puede ver en el cuadro que hubo muchas películas en cartelera en esa semana. La mayor competencia de la película en la semana fueron los holdovers, ${ }^{5}$ que aparecen en cursiva en el recuadro. Aun así, la película tuvo una buena programación con amplia cantidad de salas. De todas maneras, se considera que tuvo una apertura baja en asistencia. Debido a que la primera semana siempre es la más importante para una película, ya se podía adivinar que la película no alcanzaría fácilmente su meta.

También se ve que BF Cineplex tuvo demasiadas películas en cartelera y algunos holdovers que superaron a Horizonte profundo. BF Cineplex tuvo a El especialista: Resurrección, una película de acción, pero no de temática de desastre. Esta película tuvo como público objetivo el NSE C, mientras que Horizonte profundo tuvo al NSE AB, por lo que no se consideró una competencia directa. Como se ve en la entrevista a Diana López, gerente de marketing de Cinemark (anexo 2), en este caso se aprecia cómo un distribuidor se beneficia comercialmente de tener una oferta amplia de películas que no compiten necesariamente entre sí pero que le generan más ingresos al tener la mayor participación en el mercado. Sin embargo, se nota que debe haber sido complicado para los distribuidores lograr ajustar las salas a tal variedad de nuevas películas, cuando holdovers como La peor de mis bodas seguían llevando público a las salas.

En cuanto a las películas que no son competencia directa, Mi amigo el dragón tomó el primer lugar. Al ser una película familiar, como menciona Gabriela Absi, gerente de marketing de BF Distribution (anexo 1), llevó a familias al cine, no solo a una persona. La peor de mis bodas, al ser una película muy popular, peruana y apta a todo público, también siguió rindiendo en su tercera semana. El especialista, película de acción y aventura, siguió rindiendo en su primera semana, sobre todo gracias a que su público objetivo, NSE C de 18 a 35 años, es el mayor público de cine en el Perú. Cigüeñas fue la opción de animación, que como Mi amigo el dragón llevó familias a los cines. Miss Peregrine, que también fue familiar, siguió avanzando, aunque con resultados tibios para una película de nivel mundial. Todos los hombres son iguales tenía el beneficio de contar con Christian Meier, quien es un actor muy popular para el Perú; sin embargo, también tuvo resultados tibios. Si se toma en cuenta que esta película tuvo menos salas que Horizonte profundo y tuvo más asistencia, se considera

\footnotetext{
${ }^{5}$ Películas estrenadas anteriormente que siguen en cartelera.
} 
que le fue mejor por su promedio de asistentes por sala, lo cual la llevaría a tener más opciones de continuar en las siguientes semanas. Los otros estrenos de la semana tuvieron una asistencia menor correspondiente a su cantidad de salas, e incluso el promedio de asistentes por sala fue menor que el de Horizonte profundo.

Como suele ocurrir, la asistencia bajó fuertemente para la segunda semana. Al ambiente competitivo, ya complicado en la semana de estreno, se le sumaron tres películas complicadas: Inferno, película más grande gracias al antecedente de la precuela El código Da Vinci; Mi papá es un gato, película familiar; y El aro vs La maldición, del género de terror, que siempre vende bien en el Perú debido al público popular que predomina. Al bajar la cantidad de pantallas, también bajó fuertemente la asistencia.

Horizonte profundo quedó en puesto 11 en su segunda semana, lo cual le permitió seguir una tercera semana, pero en una cantidad de salas y horarios muy limitada, que terminó de cerrar la película con un total de 98.493 espectadores en toda su corrida. Siendo su meta 120.000 espectadores, se quedó corta por 21.507.

Rescate suicida se estrenó el 3 de noviembre del 2016, y abrió su primera semana en cuarto lugar con 77 pantallas y 85.654 espectadores.

Este fue el copiado de la película en su primera semana:

\begin{tabular}{|l|c|}
\hline CINE & Rescate suicida \\
\hline CINEMARK JOCKEY PLAZA & 1 sala \\
\hline CINEMARK SAN MIGUEL & 1 sala \\
\hline CINEMARK MEGAPLAZA & 1 sala \\
\hline CINEMARK OPEN PLAZA ANGAMOS & 1 sala \\
\hline CINEMARK PLAZA LIMA SUR & 1 sala \\
\hline CINEMARK BELLAVISTA & 1 sala \\
\hline CINEMARK AREQUIPA LAMBRAMANI & 2 funciones \\
\hline CINEMARK AREQUIPA MAPA & 3 funciones \\
\hline CINEMARK PIURA & 1 sala \\
\hline CINEMARK TRUJILLO & 2 funciones \\
\hline CINEMARK HUÁNUCO & 2 funciones \\
\hline CINEMARK CAJAMARCA & \\
\hline CINEMARK HUANCAYO & \\
\hline & \\
\hline CINEPLANET ALCÁZAR & 1 sala \\
\hline CINEPLANET LA MOLINA & 1 sala \\
\hline CINEPLANET SAN MIGUEL & 1 sala \\
\hline CINEPLANET SAN MIGUEL II & \\
\hline CINEPLANET CENTRO & \\
\hline CINEPLANET PRIMAVERA & \\
\hline
\end{tabular}




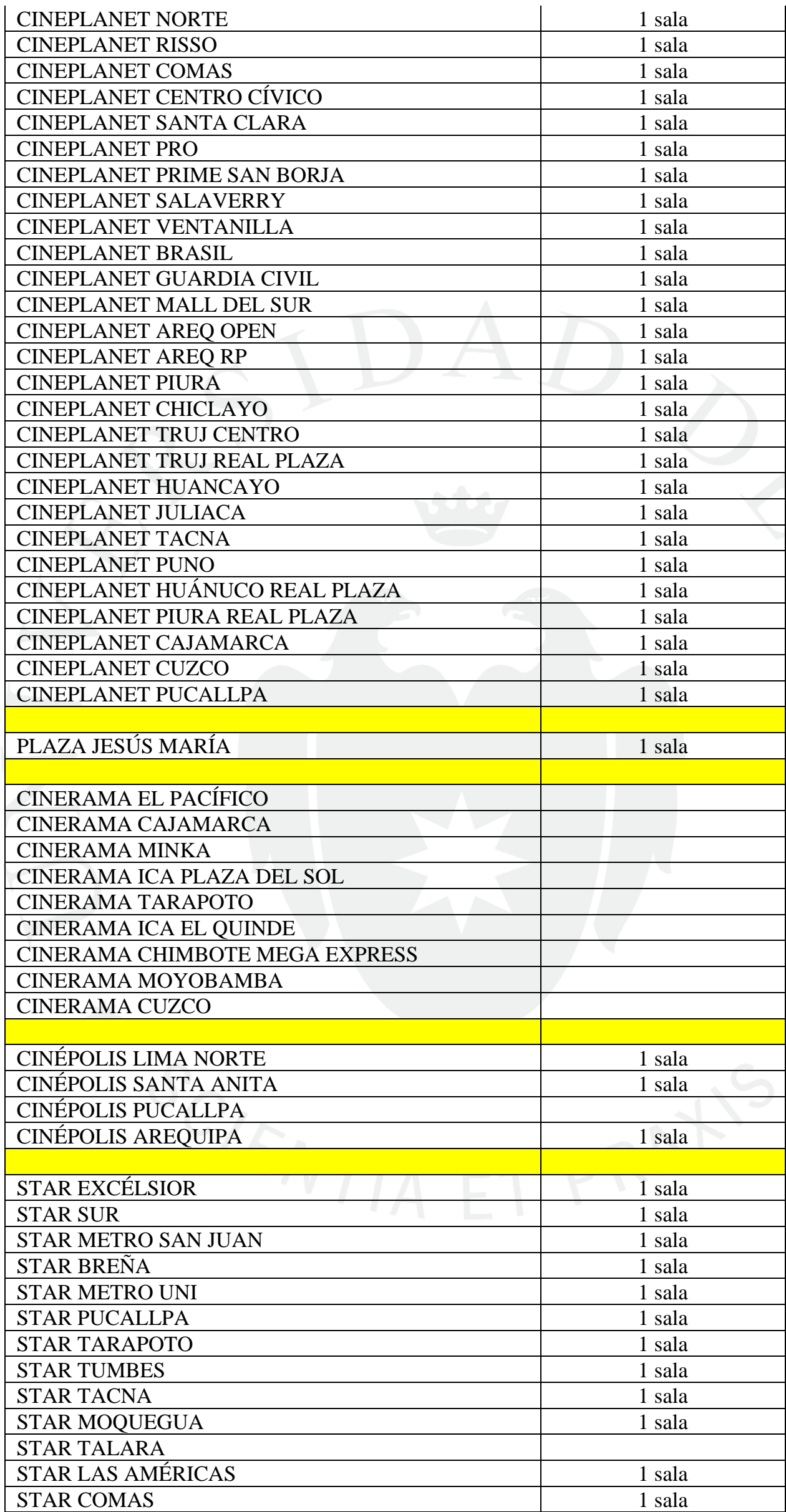




\begin{tabular}{|l|c|} 
STAR PORTEÑO & 1 sala \\
\hline STAR AVIACIÓN & 1 sala \\
\hline STAR BENAVIDES & 1 sala \\
\hline STAR IQUITOS & 1 sala \\
\hline STAR BAHÍA CHIMBOTE & 1 sala \\
\hline STAR SULLANA & 1 sala \\
\hline & 1 sala \\
\hline MOVIETIME MEGA PLAZA CHORRILLOS & 1 sala \\
\hline MOVIETIME MEGA PLAZA VILLA EL SALVADOR & 1 sala \\
\hline MOVIETIME MEGA PLAZA CHINCHA & 1 sala \\
\hline MOVIETIME CAÑETE & 1 sala \\
\hline MOVIETIME BARRANCA & 1 sala \\
\hline MOVIETIME PISCO & \\
\hline MOVIETIME JAÉN & 1 sala \\
\hline & 1 sala \\
\hline UVK ASIA & \\
\hline UVK LARCOMAR & 2 funciones \\
\hline UVK CAMINOS DEL INCA & 2 funciones \\
\hline UVK PLATINO BASADRE & 2 funciones \\
\hline UVK SAN MARTÍN & 2 funciones \\
\hline UVK EL AGUSTINO & \\
\hline UVK HUACHO & \\
\hline UVK ICA & \\
\hline UVK PIURA & \\
\hline & \\
\hline
\end{tabular}

Aquí el panorama competitivo de esa semana:

\begin{tabular}{|l|l|l|l|l|l|l|}
\hline & Película & Género & Distribuidor & Sem. & Pant. & Adm. Sem. \\
\hline 1 & Doctor Strange & Acción & Cinecolor & $\mathbf{1}$ & $\mathbf{9 2}$ & $\mathbf{3 5 3 8 8 5}$ \\
\hline 2 & Trolls & Animación & $\begin{array}{l}\text { New Century } \\
\text { Films }\end{array}$ & 2 & 92 & 131993 \\
\hline 3 & Siete semillas & Comedia & $\begin{array}{l}\text { New Century } \\
\text { Films }\end{array}$ & 3 & 77 & 101328 \\
\hline 4 & Rescate suicida & Acción & BF Cineplex & $\mathbf{1}$ & $\mathbf{7 7}$ & $\mathbf{8 5 6 5 4}$ \\
\hline 5 & Ouija: el origen del mal & Terror & UIP & 3 & 38 & 40929 \\
\hline 6 & Una pareja dispareja & Acción & BF Cineplex & 2 & 40 & 36027 \\
\hline 7 & Permitidos & Comedia & Delta & $\mathbf{1}$ & $\mathbf{3 3}$ & $\mathbf{1 6 3 4 8}$ \\
\hline 8 & Condenados al infierno & Terror & Star Films & $\mathbf{1}$ & $\mathbf{3 1}$ & $\mathbf{1 6 0 1 0}$ \\
\hline 9 & Inferno & Acción & Andes & 4 & 19 & 14328 \\
\hline 10 & Mi papá es un gato & Familiar & Diamond & 4 & 24 & 14092 \\
\hline 11 & El contador & Drama & $\begin{array}{l}\text { New Century } \\
\text { Films }\end{array}$ & 3 & 15 & 11882 \\
\hline 12 & Robert, el muñeco diabólico 2 & Terror & Mundo Films & -1 & 7 & 5314 \\
\hline 13 & El aro vs. La maldición & Terror & Star Films & 4 & 4 & 4776 \\
\hline 14 & Enemigos en la red & Suspenso & Andes & 2 & 9 & 4320 \\
\hline 15 & Mi amigo el dragón & Familiar & Cinecolor & 5 & 8 & 2916 \\
\hline 16 & La peor de mis bodas & Comedia & BF Cineplex & 7 & 1 & 907 \\
\hline 17 & $\begin{array}{l}\text { El especialista: la } \\
\text { resurrección }\end{array}$ & Acción & BF Cineplex & 6 & 1 & 445 \\
\hline 18 & El abogado del mal & Suspenso & Delta & 3 & 1 & 441 \\
\hline 19 & El choque de dos mundos & Documental & Cinecolor & 4 & 2 & 378 \\
\hline 20 & $\begin{array}{l}\text { Miss Peregrine y los niños } \\
\text { peculiares }\end{array}$ & Familiar & $\begin{array}{l}\text { New Century } \\
\text { Films }\end{array}$ & 6 & 2 & 268 \\
\hline 21 & Cigüeñas & Animación & $\begin{array}{l}\text { New Century } \\
\text { Films }\end{array}$ & 7 & 3 & 177 \\
\hline
\end{tabular}


A pesar de que hubo casi la misma cantidad de películas que en la semana de Horizonte profundo, se puede ver que a partir del puesto 12 los holdovers no representaron un porcentaje importante del market share. En cuanto a la competencia por género, Rescate suicida se estrenó con un blockbuster, Doctor Strange, que obtuvo el 42\% del market share. Además, compitió con Una pareja dispareja, una película con Jackie Chan, actor muy querido en el territorio, que además tenía toques de comedia, el segundo género más importante en el Perú. En este contexto, a Rescate suicida le fue como se esperaba. Abriría mejor que Una pareja dispareja por ser su primera semana, pero quedaría detrás de Doctor Strange. En el ranking, siguió Trolls - la película infantil de la semana - en su segunda semana, y Siete semillas, película peruana con el actor más popular del Perú, Carlos “Cachín” Alcántara.

Para su segunda semana, la cantidad de salas bajó a 37. Las películas que más complicaron la programación fueron Calichín y Jack Reacher. Calichín, película peruana sobre fútbol en la cual se tenían expectativas muy altas, abrió con 93 salas, lo cual afectó a los holdovers. Sin embargo, la disminución de espectadores en su segunda semana fue lo esperado y siguió llevando espectadores a los cines, lo cual permitió que la película siguiera en cartelera hasta una quinta semana. La película cerró con 118.532 espectadores, superando su meta de 100.000 espectadores.

Frente a la apertura de Horizonte profundo, Rescate suicida abrió en 9 salas menos, pero hizo más espectadores, teniendo un promedio de 1.112 frente a los 896 de Horizonte profundo. 


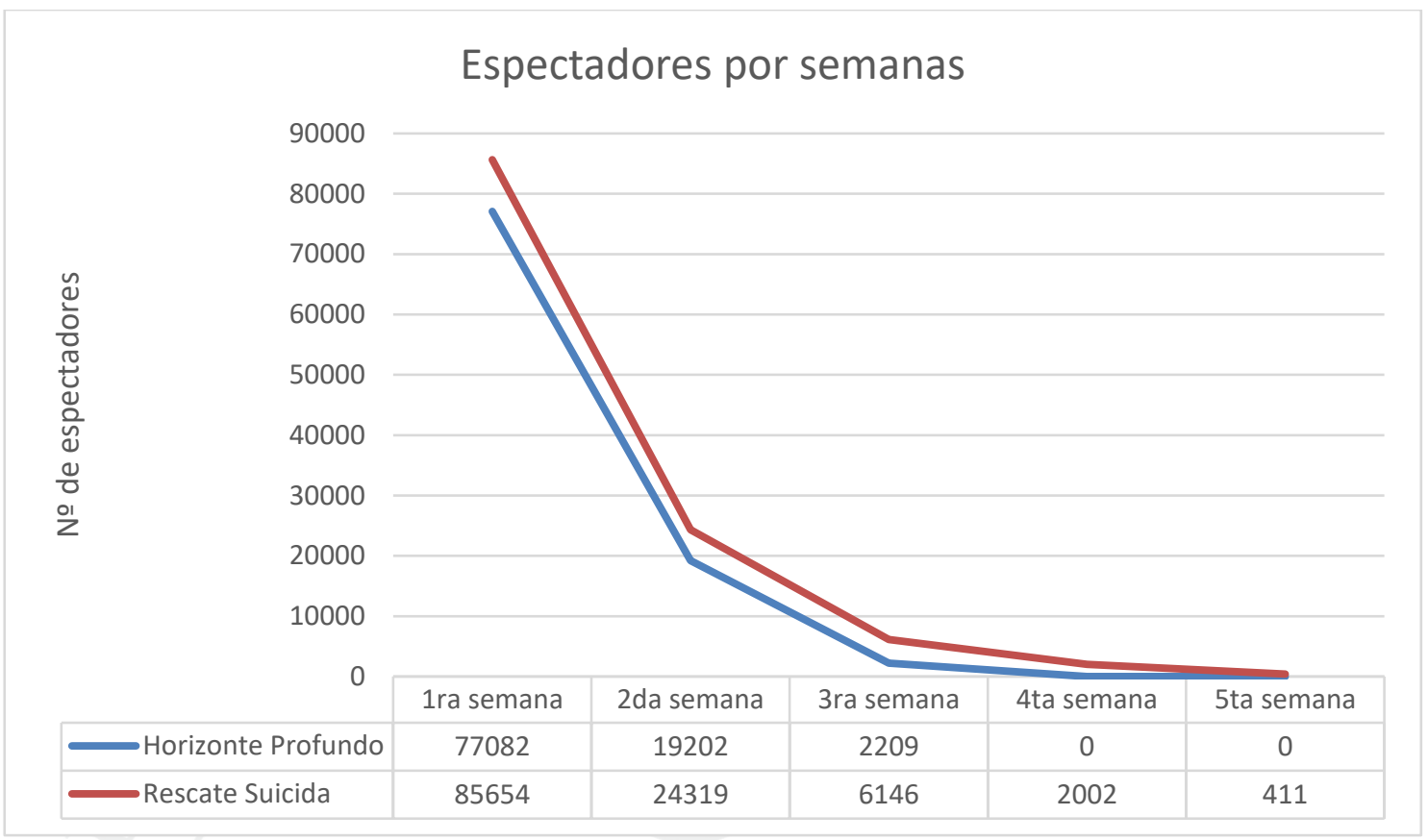

Fuente: Rentrak

La disminución de espectadores y de salas luego de la primera semana de las películas fue más favorable para Rescate suicida. Esto se debe a la asistencia y al ranking de las películas. En el caso de estas películas, el word-of-mouth ${ }^{6}$ no fue relevante. Hay algunos casos, como menciona Diana López, en los que las recomendaciones de los espectadores encienden la película, pero esto no suele ocurrir para películas de acción. Por lo tanto, la asistencia dio como resultado el ranking de películas, y la posición de ambos filmes en este ranking, frente al resto de títulos, definió la programación de las películas en cartelera.

\footnotetext{
6 Situación en la que los espectadores dan buenos comentarios de la película, lo cual hace que la asistencia aumente o se mantenga en las semanas luego de la primera en cartelera.
} 


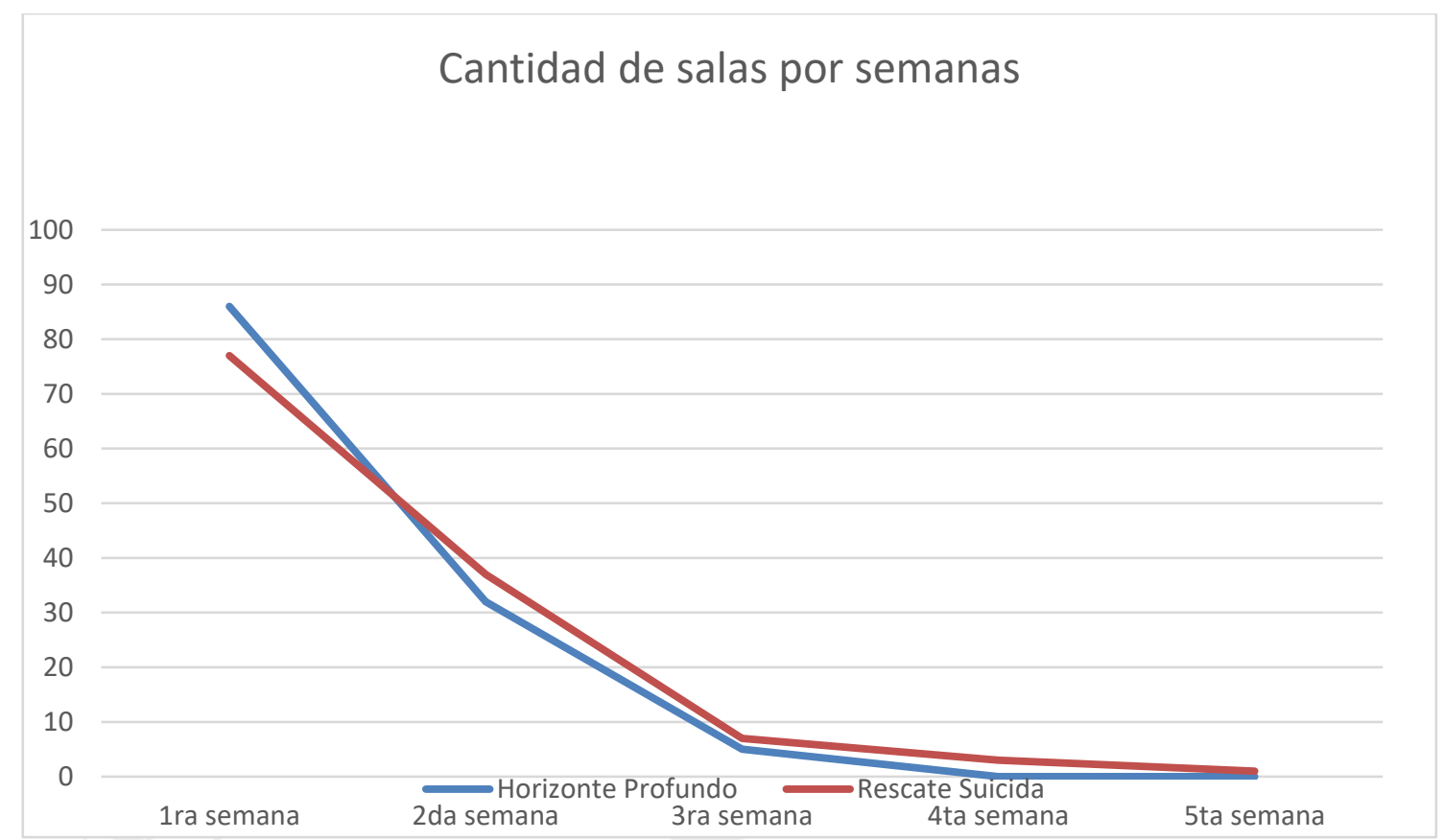

Fuente: Rentrak

Al final, Rescate suicida hizo 20.000 espectadores más que Horizonte profundo, superando su objetivo y cumpliendo 5 semanas en cartelera, frente a las 3 de Horizonte profundo, que siguió teniendo resultados malos.

En cuanto al marketing, las campañas siempre se enfocan previamente al estreno, como contaron las entrevistadas (anexos 1 y 2). Rescatar a una película ya en su segunda semana de estreno es muy difícil, a menos que el word-of-mouth ayude. Por esto, en ambos casos, las únicas actividades de marketing o de comunicación que se dieron fueron por redes sociales sin inversión. 


\section{CONCLUSIONES}

La distribuidora trabajó ambas películas de manera muy similar, pero sí hubo algunas diferencias que se pueden tomar en cuenta. A pesar de que Horizonte profundo no fue un fracaso y cumplió con llevar espectadores a los cines, la distribuidora sí esperaba que convocase algo más de público. Sin embargo, Rescate suicida, para la que se tenían menos expectativas, rindió mucho más y superó su meta. De la comparación de las campañas, se puede concluir lo siguiente:

- Las características intrínsecas de la película (género, nacionalidad, tema, actores, guion, etcétera) solo son relevantes para el éxito de una campaña de marketing en cuanto se sepa elegir el público objetivo correcto y se refuercen algunos conceptos solo si las circunstancias lo ameritan. Con esto me refiero a que, si la película tocara el tema de la corrupción política y en el país hubiera un escándalo de ese tipo, el tema se podría explotar. Sin embargo, enfocar la campaña en actores o en un tema alejado como "basada en hechos reales" de otro país no ayudó a Horizonte profundo. En cambio, enfocarse en algo genérico como "desastre", "avión estrellado", "explosiones", etcétera, funcionó muy bien para Rescate suicida. Horizonte profundo también tenía esos conceptos, pero no fue el enfoque de su comunicación. Considero que, si Horizonte profundo se hubiera dirigido más al sector popular, podría haber obtenido mejores resultados.

A pesar de lo opinado por Diana López, parece que la nacionalidad no tiene mucha importancia siempre que el idioma en el que se presente la película sea español. Como mencionan las 
entrevistadas, las películas en formato doblado atraen más espectadores que las subtituladas. Por este motivo, sin importar la nacionalidad de la producción, si el nivel de calidad se asemeja al de Hollywood y la película se presenta doblada, parece tener las mismas oportunidades que las estadounidenses. Sin embargo, si la comunicación de la campaña se enfoca en la nacionalidad extranjera de la película, es muy probable que se cumpla lo que Diana López comenta. Es una característica que no ayuda a la promoción de la película, a menos que se trate de un filme de terror japonés.

- En cuanto a los materiales creativos, lo más efectivo resulta ser lo más simple. Mientras más claro sea el mensaje y más rápido se entienda el concepto en un póster, será mejor recibido por el espectador. En Rescate suicida se retiraron los elementos que no sumaban a los conceptos para la comunicación de la película y se dejó, en primer plano, el avión estrellado en llamas con el título grande y contrastado con el fondo. En Horizonte profundo, aunque haya sido por un tema contractual, hubo elementos que no lograron llegar al público. La mayoría de personas no sabe cómo se ve una plataforma petrolífera, y, aunque hubo fuego y humo, el espectador no la logra identificar tan rápido como a un avión. El rostro fantasmal de Mark Wahlberg, además, genera una confusión del género cinematográfico. Ya no solo es acción-desastre, sino que ahora tiene también drama.

Esto mismo se extiende en todos los materiales de la comunicación de la película, ya que son representaciones y adaptaciones del mismo concepto artístico. Tanto en el POP como en la vía pública de Horizonte profundo, se le dio importancia a la plataforma petrolífera, a la línea de "basado en hechos reales" y al rostro de Mark Wahlberg (según lo permitiera el contrato). Sin embargo, en Rescate suicida se usó el concepto del avión para los medios y promociones, y una variedad de adaptaciones de otras propuestas de arte en el POP, pero que aun así mostraban el concepto de acción y adrenalina en medio de un desastre.

- En cuanto a la exhibición en medios, Rescate suicida tuvo una presencia mucho mayor en televisión abierta y cable que Horizonte profundo. A 
pesar de que no es la temática preferida del público según el estudio "Hábitos y actitudes hacia la televisión" (Ipsos, 2015) — los elementos preferidos son situaciones divertidas, ambientes naturales, ambientes hogareños y música agradable-, y de que el spot de la película no tenía nada de eso, la exhibición en televisión parece haber aportado a los buenos resultados de la película.

- Asimismo, Rescate suicida tuvo mayor presencia que Horizonte profundo en la vía pública, específicamente en el Metro de Lima y en centros comerciales, con pantallas digitales. Según "Hábitos y actitudes haca los medios de comunicación alternativos" (Ipsos, 2015), entre el tipo de publicidad de mayor agrado están los videos. Además, la penetración más alta es la publicidad exterior. Este puede haber sido el punto diferencial más importante, ya que Rescate suicida tuvo videos en ubicaciones exteriores, mientras que Horizonte profundo solo los tuvo en iWalls dentro de centros comerciales. A pesar de que igual es bueno tener ese tipo de presencia, el formato gigante de las pantallas en la vía pública causa un mayor impacto.

- Horizonte profundo partió con la campaña de POP en un tiempo muy cercano a su estreno. Esto puede haber jugado en contra ya que, a pesar de que había elementos especiales, tuvieron menor tiempo de exhibición que los elementos simples de Rescate suicida. Además, como se mencionó anteriormente, los conceptos comunicados no fueron tan claros y fáciles de captar en Horizonte profundo como lo fueron para Rescate suicida. Entonces, la prioridad en la campaña en punto de venta es el tiempo y cantidad de exhibición más que el formato de los elementos.

- En cuanto a la importancia de la programación, definitivamente la cantidad de salas con las que arranque una película le dan la posibilidad de conseguir la asistencia que requiere en su primera semana para asegurar una buena corrida y llegar a su meta. Pero esto no significa que toda la campaña de comunicación sea opcional. Como afirma Diana López, el exhibidor tomará en cuenta qué tanto está sonando una película para que se logre, a través de la negociación, un buen trato de 
programación. Además de hacerlo por el exhibidor, las campañas de promoción de las películas afectan la decisión de compra. También depende de cuánto el consumidor conoce al producto: ya sea que vaya al cine por ver una película específica, o que la elija en la boletería, el consumidor preferirá una película si ya escuchó sobre ella.

- Para llegar al consumidor, es importante encontrar los espacios en los que el público objetivo se mueve. En este sentido, es importante hacer una campaña 360 que cubra todos los puntos. En los casos de las películas en cuestión, ambas campañas tuvieron presencia en la vía pública, medios ATL, redes sociales, centros comerciales, tiendas de marcas que el público conoce y consume, y en los mismos cines. No se podría decir que, por ejemplo, solo hacer vía pública logrará un buen resultado para la película si esto significa que se descuiden los otros espacios de comunicación.

- Considero que las películas pudieron haber tenido inversión en redes sociales. Teniendo un público objetivo juvenil y con la penetración de la publicidad en redes sociales, hoy en día se debe reforzar la presencia del avance del filme, sobre todo en espacios virtuales. En el estudio de Google y Millward Brown (2016) se afirma que siete de cada diez peruanos consideran el avance como algo decisivo para elegir una película. Asimismo, se afirma que de los que vieron el avance previamente, $89 \%$ lo hizo en YouTube. Por esto es importante considerar a las redes sociales como un espacio en el cual invertir y no solo con publicaciones orgánicas.

Estrenar una película extranjera chica o mediana puede ser rentable en la industria nacional si se utilizan todas las herramientas de promoción de manera eficiente. Se deben comunicar los conceptos que más atraen al público peruano y obviar los que no aportan al interés de la audiencia, como, en este caso, la nacionalidad de la producción. Las películas y los materiales promocionales deben estar en español, el doblaje es muy importante para todas las películas en idioma extranjero. Asimismo, los mensajes deben ser claros y directos para ser efectivos. Las campañas de marketing deben abarcar todos los espacios donde se mueve el público para que tengan en mente a la película, de manera que a la hora de elegir qué ver en el cine la tengan en mayor 
consideración. Esto comprueba que no hay un área de las campañas de marketing que sea más o menos importante que el resto. Ambas campañas se trabajaron de manera muy similar, pero la diferencia de resultados de taquilla estuvo en las decisiones estratégicas sobre los conceptos comunicados en las campañas promocionales de ambas películas. 


\section{BIBLIOGRAFÍA}

Akamine, J. (10 de abril del 2017). ¿Cómo se mueve la industria cinematográfica en el Perú? El Comercio. Recuperado de:

http://elcomercio.pe/movil/eldominical/actualidad/cartelera-cine-fondo-pantalla-noticia$\underline{1982263}$

Google y Millward Brown (2016). ¿Cómo decidimos qué ver en el cine? Recuperado de: https://storage.googleapis.com/think/docs/00LATAM/201608/16-0816\%20MovieGoers\%20Infografi\%CC\%81a-Final_\%20Peru\%CC\%81.pdf

Hendrickx, N. (2010). Perspectivas y posibilidades de crecimiento del cine peruano en el contexto mundial. (Tesis de maestría). Pontificia Universidad Católica del Perú. Recuperada de: http://tesis.pucp.edu.pe/repositorio/handle/123456789/1376

Herbera, J., Linares, R. \& Neira, E., coords. (2015). Marketing cinematográfico: cómo promocionar una película en el entorno digital. Barcelona: Editorial UOC. ProQuest ebrary. Web. 26 de abril del 2017.

High End Cine (2015). El cine está lleno de experiencias. Lima.

Ipsos (2015). Hábitos y actitudes hacia los medios de comunicación alternativos. Lima: Ipsos Apoyo Perú. Recuperado de Marketing Data Plus. Web. 26 de abril del 2017.

Kerrigan, F. (2010). Film Marketing. Oxford, Reino Unido: Elsevier.

Miller, T., Govil, N., McMurria, J. \& Maxwell, R. (2005) El nuevo Hollywood. Del imperialismo cultural a las leyes del marketing. Barcelona: Paidós, 2005.

Miñarro, L. (2014). Cómo vender una obra audiovisual. Una aproximación a la distribución de contenidos audiovisuales. Barcelona: Editorial UOC.

Neira, E. (2013). El espectador social. Las redes sociales en la promoción cinematográfica. Barcelona: Editorial UOC.

Pérez, J. (2010). El cartel de cine hoy. Pensar la Publicidad, IV (2), 71-88. 
Redondo, I. (2000). Marketing en el cine. Madrid: Ediciones Pirámide.

Rentrak (2017). International Box Office Essentials (26 de marzo del 2018).

Recuperado de: $\underline{\text { www.iboe.com }}$

Tamayo, A. \& Hendrickx, N. (2008). Financiamiento, distribución y márketing del cine peruano. Lima: Fondo Editorial de la Universidad de Lima.

Wilson, R. (2007). Measuring the impact of motivation, opportunity, and the ability on the recall of out-of-home advertising: The case of cinema advertising. (Tesis de doctorado). De la base de datos ProQuest Dissertations and Theses (UMI N. ${ }^{\circ} 3280235$ ). 
ANEXOS 


\section{ANEXO 1: ENTREVISTA A GABRIELA ABSI, GERENTE DE MARKETING DE BF DISTRIBUTION}

Para promocionar una película, ¿cuáles son las características de la misma que más se busca explotar?

Todo va a depender del público objetivo de la película y de la meta que queremos alcanzar. Por ejemplo, si es una película de terror, sabemos que nuestro público es juvenil y en su mayoría hombres, es por eso que la campaña debe estar dirigida a ellos. Las características que explotaremos serán las imágenes sugestivas de terror que llamen la atención del público, el tema del que trate la película: demonios, exorcismos, secuestros, etcétera.

Otra característica importante es el cast de la película. Definitivamente es muy importante si la película cuenta con actores conocidos, esto se explotará en la campaña, buscando generar afinidad con el público objetivo.

Y finalmente, podría decir que, en estos últimos tiempos, una característica importante para las películas es si están relacionadas a un suceso de moda como el acoso o las redes sociales, o si están basadas en un libro que sea muy conocido o best seller.

¿El público objetivo es determinante para establecer una meta de espectadores a una película?

Sí, es lo más importante. No es lo mismo estrenar una película familiar, donde sabemos que la asistencia al cine será del papá, la mamá y los hijos, que una película de terror, cuya ocasión de compra, viéndolo desde el punto de vista comercial, es muy diferente. Incluso la meta será mucho menor para una película de arte, donde la ocasión de compra está relacionada a una temporada de premios o a la recomendación de una persona.

Esto hace que, en nuestro país, las películas familiares sean más comerciales, porque el consumo de estas se realiza de forma masiva, sin distinción de público, lo que ha 
llevado a que el cine se convierta en un elemento de distracción más: una salida al cine cuenta como una salida familiar de fin de semana.

En el caso de 'Rescate suicida' y 'Horizonte profundo', hubo más exhibición en medios para 'Rescate suicida'. ¿Esto puede ser el motivo de sus mejores resultados?

Definitivamente, las campañas de marketing son muy importantes para el desenvolvimiento de nuestras películas. Nosotros procuramos que todo el esfuerzo, inversión y publicidad se realice antes del estreno, para que el público sepa de la película antes y la elija en su primer fin de semana de estreno.

En este caso, por el tema de la película y como estrategia, se decidió que Rescate suicida era una película para un público popular, a diferencia de Horizonte profundo, ya que consideramos que, por el tema, y al estar basada en hechos reales, podría llamar la atención de un público más selecto. La inversión fue mayor en Rescate suicida porque tratamos de llegar a más público, a diferencia de Horizonte profundo, donde la inversión fue puntual y más selectiva. Los resultados fueron buenos para ambas, porque teníamos metas diferentes, de acuerdo al público y a la cantidad de salas con las que estrenamos.

¿Qué vale más para los resultados de taquilla, una buena campaña de marketing o la fecha y películas de la competencia con que se estrena la película?

No hay una respuesta correcta, ni una fórmula secreta. El gran secreto es la mezcla y el buen análisis de todo lo que mencionas. Por ejemplo, vamos a hablar de la película peruana Calichín, que se estrenó hace poco. Tuvo una gran campaña de marketing, con el respaldo de los actores locales y toda una inversión que se vio reflejada en su presencia a nivel nacional. Sus resultados fueron buenos, pero seguramente no los que ellos esperaban: sumaron 900.000 espectadores, pero estoy segura de que su meta fue mucho mayor. Lo que yo creo es que, a pesar de que tuvieron una buena campaña, la fecha en la que estrenaron no fue la mejor: ellos salieron entre Annabelle y El planeta de los simios, lo cual a mi parecer no fue lo más acertado, porque ambas películas son gigantes blockbusters que acapararon la taquilla semanas antes y semanas después, lo cual no les permitió tener continuidad en la cartelera; es decir, no fue la primera opción 
del público, por lo que no tuvieron mucha gente en su primera semana y no pudieron permanecer con muchas pantallas para las siguientes.

Y así podemos analizar películas internacionales como Valerian, que tuvo también una buena campaña de marketing, una buena fecha, pero la película no gustó del todo y no se conectó con el público objetivo. Por nuestro lado, también tenemos la película Power Rangers, con la que cumplimos los objetivos, pero pudo ser mejor. En este caso, nos afectaron los desastres naturales del Fenómeno del Niño, lo cual disminuyó la asistencia al cine a nivel nacional.

En resumen, la suma de todos los factores afecta o influye mucho en el desempeño de la película. Hay que tomar en cuenta todos esos factores, plantear estrategias para cada uno y adecuarnos al entorno de la competencia y al contexto en el que se desenvuelve el público objetivo. Podría decir que es muy similar a una campaña de marketing de un producto o servicio cualquiera.

Según su experiencia con películas no americanas, ¿la nacionalidad de la película es un factor importante?

Si hablamos de las películas peruanas, la nacionalidad es lo más importante. Debido al resurgimiento del cine peruano, cada vez es más importante la presencia y las campañas de las películas peruanas. El público es más receptivo a las películas peruanas y se han convertido en gran competencia para las películas internacionales.

En cuanto a las películas europeas, que son en su mayoría francesas, aunque también hay varias producciones españolas, solo un sector del público es conocedor de este tipo de cine y las van a ver por su nacionalidad. Lo que hacemos nosotros como distribuidora es explotar el género de la película, comedia, drama, y venderla por ese lado, más que por su nacionalidad. De todas formas, buscamos aliados relacionados al cine francés, como la Embajada de Francia o la Alianza Francesa, con los que también llegamos a este pequeño público que sí conoce de este cine.

También se puede decir que hay mucho cine latinoamericano, como mexicano, argentino, chileno, que ha tenido éxito en nuestra cartelera. Pero es lo mismo: no funciona por su nacionalidad, sino por el género. $\mathrm{O}$, en este caso, también puede 
funcionar si hay algún actor o actriz conocida que destaque en nuestro país por alguna novela o teleserie, y que llame la atención del público.

\section{¿Y los actores?}

Como dije en la pregunta anterior, en el caso de las películas latinoamericanas hay más afinidad por el lado de los actores, aunque también podría funcionar en las películas europeas, donde algunos actores también son conocidos.

De todas formas, insisto en que este no es un factor de éxito. A nivel comercial, personalmente opino que lo más importante con estas películas es explotar el género, ya que no todos conocen a los actores o los siguen, a menos que sea un actor de Hollywood y que ya haya participado en películas grandes; se me viene a la mente Eugenio Derbez como ejemplo. Un actor como él hace que la película pase de ser simplemente mexicana y la convierte en casi un blockbuster, como nos pasó a nosotros con No se aceptan devoluciones y recientemente con Cómo ser un 'latin lover', que sí tenía producción americana, pero lo tenía a él como activo más importante para la película.

¿La decisión de doblar al español las películas ha resultado? ¿El público prefiere las películas dobladas?

Este punto se me quedó pendiente en las películas anteriores. Como dije que, en nuestro caso, tratamos de vender las películas más por el género que por su nacionalidad, una de las cosas que nos han resultado para el mercado peruano es doblar al español estas películas y también las americanas.

Al principio, teníamos mucha desconfianza sobre esto, pero ha quedado comprobado con muchas películas que los resultados son mejores cuando tenemos la versión doblada para cines populares y cuando tenemos acceso a horarios familiares en cines donde no podríamos estar presentes con una película subtitulada.

Tratamos de doblar todas sin distinción, películas de acción, comedia, familiares, y bueno, las animadas, que de por sí deben ser dobladas para tener mayor acogida con los niños. 
¿Cuáles pueden ser los motivos por los que 'Rescate suicida' llegó a su meta y 'Horizonte profundo' no?

El primero que se me ocurre es que el título y el arte de Rescate suicida tenían nociones de "destrucción" y "fin del mundo", que son conceptos que atraen al público de ese género. Horizonte profundo tenía un arte complicado, y a pesar de tener a Mark Wahlberg, el tema no era tan afín con el público. La diferencia de resultados fue muy poca. Horizonte profundo no llegó a su meta más por un tema de programación, tuvo una mantención más baja que Rescate suicida. Además, Rescate suicida se trató más para el sector popular y el grueso de los asistentes de cine está en ese sector, por eso vendió un poco más. 


\section{ANEXO 2: ENTREVISTA A DIANA LÓPEZ, GERENTE DE MARKETING DE CINEMARK}

'Horizonte profundo' es una película americana y 'Rescate suicida' es una película rusa. ¿Tú crees que la nacionalidad de las películas es relevante para sus resultados? Sin tomar en cuenta las peruanas, porque esas son otro tema.

Sí, muy relevante. Si es que el país es como referente del género, pesa un poco más. Creo que de esos casos solamente un Japón se lleva el trofeo de terror. Pero de ahí, el resto de países a nivel comercial no es que exploten tanto el país de referencia, la película, para que realmente sea un buen éxito de taquilla. Creo que hay otras variantes adicionales que juegan a favor de la comercialización de una película más allá del país. A menos que sea terror, igual Japón. El resto de países no es que marquen algo determinante.

¿Tú encuentras que la campaña de 'marketing' sea muy relevante para los resultados? Si hubo diferencias entre la campaña que se le hizo a una versus la que se le hizo a la otra, ¿no es necesariamente el motivo por el que a una le fue bien y a la otra no tan bien?

Siempre va a sumar, porque sin comunicación una película no existe, pero hay muchas variables más que juegan a favor de que el resultado vaya bien.

'Horizonte profundo', al tener más drama, se le orientó a un público AB, mientras que 'Rescate suicida' se quiso vender más al popular. ¿Crees que eso haya tenido que ver? Porque el público popular es más amplio.

Sí, de hecho, sí. Tiene muchísimo que ver. Desde el plan que armas, el target al que te diriges.

¿Cuánto o de qué manera tú crees que beneficia el doblaje a las películas en otros idiomas acá en el Perú?

En líneas generales, las personas y el público creen que quieren o que prefieren más lo subtitulado; finalmente la tendencia es al revés, más orientado a lo doblado. Entonces 
sí, el tener la película doblada suma mucho a que el attendance de una película vaya mejor. Hay una marcada diferencia por exhibir una película doblada versus una subtitulada. Si es que tú pones dos salas, una doblada y otra subtitulada, la doblada siempre va a llenar, la subtitulada va a quedar en menos de la mitad. Entonces, comercialmente hablando, las dobladas tienen mayor aceptación por el público. Tanto para acción, animación... incluso para las románticas el doblaje funciona bien. Es muy nicho el sector que prefiere subtitulado. Precisamente porque es muy nicho, tener una sala de 250 personas no es rentable para el cine, ponerla subtitulada para que tenga ocupación del $20 \%$, del $15 \%$... más si es una película que no vas a abrir en tres pantallas o dos pantallas al mismo tiempo. Si es una película que va a abrir en una sola pantalla es mucho más rentable para nosotros ponerla doblada por indicadores de ocupabilidad de sala.

\section{¿Qué tan conveniente o rentable ves estrenar películas chicas o medianas?}

Es como parte de la variedad de tu cartelera anual. Cuando uno hace una proyección de negocio necesitas tener momentos de venta relevantes durante el año y para eso existe un mix de productos. Entonces, así como una marca de consumo masivo puede generar productos de muy alta rotación a muy bajos márgenes, tiene productos de poquísima rotación, pero con un muy buen margen. En este caso ocurre un poco lo contrario, pero es básicamente la misma lógica. Tienes un montón de productos chiquitos que al final te forman un consolidado y por volumen una buena participación o facturación activa durante el año que sopesa el hecho de que no tengas tantos blockbusters, como un Disney. Inclusive Disney hoy en día está buscando mucho producto alternativo bajo la misma lógica. No te puedes quedar únicamente con los blockbusters porque no se producen más que cinco al año por estudio y estoy exagerando. Entonces es demasiado relevante tener productos que mantengan el negocio vivo, como distribuidor, de cara al distribuidor, porque el estudio es otro tema.

¿Cuánto le conviene al exhibidor apoyar estas películas medianas? ¿O en qué medida?

Como exhibidor, como el margen sigue siendo el mismo para todas las películas, a nosotros lo que nos genera volumen es lo que nos va a hacer negocio. Tener muchas películas chicas o medianas nos juega en contra en la medida en que no tenemos tanta cantidad de salas para ponerlas una película por sala, y si a eso le sumo un calendario 
muy activo de estreno tras estreno, no voy a tener vitrina de exhibición para todas las películas que quieran poner más, porque tienen una ocupación baja. Entonces, de cara al exhibidor, no es tan rentable tantas películas estrenándose al mismo tiempo. Es mucho mejor tener películas que funcionen bien y que te llenen sala y poder mantenerlas en cartelera porque es bien conocido también que las películas se demoran en calentar. Entonces, la primera semana es como el shop más fuerte de attendance, a menos que sea un Coco, que fue completamente lo opuesto, o un Extraordinario, que también empezó bajo y luego subió por el boca a boca. Fuera de películas como estas dos que te acabo de mencionar, la película muere a la primera semana, o a la segunda semana y media ya le quitaron salas. Es un hilo muy delgado entre la necesidad del distribuidor de ir generando ingresos y la del exhibidor de rentabilizar la ocupabilidad que podamos tener en sala, para ver que efectivamente, si tú estrenaste la película A y la próxima semana viene el distribuidor $\mathrm{X}$ y te pone la película $\mathrm{B}$, es obvio que la película, por ser estreno, va a tener más attendance que la $\mathrm{A}$, a menos que no sea tan conocida. Entonces, qué tanto nos juega a favor, pues depende de toda la bulla que haya detrás de la película. Más si es una película mediana. Es superimportante tener el background de cuánta promoción se le hizo, qué tan bien voceada y conocida está la película, y desde ese punto de vista creo que es superimportante siempre tener las campañas de marketing con anticipación al estreno, calentar muy bien la fecha de estreno de la película para que no pase como un estreno desapercibido.

Dentro de las campañas de 'marketing', ¿crees que haya un área que sea más importante que las otras?

Lo que pasa es que cada cosa cumple un rol diferente. Siempre se habla de tener una campaña 360 y creo que es superimportante mantenerlo de esa manera, porque tu pauta en medios cumple un rol de difusión de la película previo al estreno. El material en punto de venta termina de aterrizar la decisión de compra en el punto de venta, el punto caliente para ustedes. Porque ahí es donde tienes los pósteres de todas las películas. Si no escuchaste nada previamente de la película Rescate, vas a priorizar cualquiera otra película de la que ya escuchaste en la radio, en la tele, en donde sea. Prensa, a nivel promocional, sí, siempre hay un público que se informa un poco más antes, además de que las noticias se inician un poco por ahí. Siempre es una oportunidad, no gastaría ahí tanto esfuerzo, porque al final es contenido para revistas, diarios, entonces sí o sí te lo 
van a publicar. Luego está todo el tema promocional que es generarle actividad a la película de la mano de socios estratégicos que lleguen a los consumidores. Creo que también es supervalioso para completar el 360.

En tu experiencia con el público acá en el Perú, ¿cómo crees que eligen ver una película entre todas las opciones que hay? ¿Crees que la decisión ocurre en el cine o fuera del cine?

Pues depende, hay todo tipo de consumidor. Pero si estamos hablando de tus películas, a menos que sea un blockbuster es muy difícil que la decisión esté hecha antes de salir al cine. Creo que la decisión va más por el momento. “¿Qué hacemos? Vamos al cine. Ya, revisa qué hay en cartelera". Y ahí viene el "he escuchado de esta película". Entonces dentro del proceso de decisión de qué vamos a hacer, el "vamos al cine porque he visto tal película en la calle, vamos a verla" es muy... no tengo un número claro, ni una estadística real para decirte: no, primero deciden ir al cine y de ahí ve la película o primero alguien ha escuchado sobre la película y después deciden ir al cine. No he hecho una investigación así, pero diría que es como a medias. Ahí influyen ambos: Tengo una promoción para una determinada película o tengo una promoción para cartelera regular. No te podría dar una respuesta cierta porque no tengo una estadística para que yo diga: no, así es. Yo creo que suceden las dos cosas. ¿Cuál pesa más? Te mentiría, no sé cuál es la que pese más. Personalmente, me pasa que he oído de la película y quiero verla sí o sí, o no tengo nada que hacer y digo: "vamos al cine, ¿qué hay en cartelera?". De ahí viene el "he escuchado que esta película es buena". Pero, sí, principalmente si he escuchado que esta película es buena, voy a verla. 